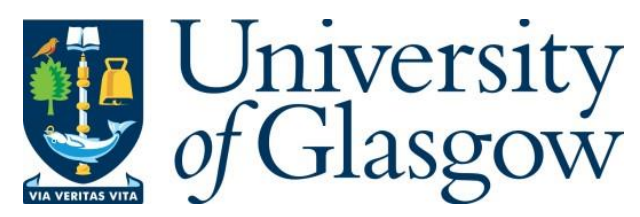

Eichenauer, V. Z. and Reinsberg, B. (2017) What determines earmarked funding to international development organizations? Evidence from the new multi-bi aid data. Review of International Organizations, 12(2), pp. 171-197.

There may be differences between this version and the published version. You are advised to consult the publisher's version if you wish to cite from it.

http://eprints.gla.ac.uk/172865/

Deposited on: 5 November 2018

Enlighten - Research publications by members of the University of Glasgow http://eprints.gla.ac.uk 


\title{
What determines earmarked funding to international development organizations? Evidence from the new multi-bi aid data
}

\author{
Vera Z. Eichenauer (Heidelberg University, KOF ETH Zurich) \\ Bernhard Reinsberg (University of Zurich, University of Cambridge)
}

\begin{abstract}
Earmarked aid to international organizations has quadrupled over the last two decades and now represents almost twenty percent of total aid. This paper introduces a new dataset on earmarked aid, which alternatively has been referred to as multi-bi, restricted, non-core or trust fund aid. The data make it possible to track the rise of the new aid channel over an extended time period and in greater detail regarding, e.g., the implementing multilateral organizations. The data include more than 100,000 earmarked projects of 23 OECD donors to 290 multilateral institutions from 1990 to 2012. We graphically illustrate the patterns in earmarked aid for all actors: donor governments and their aid-providing agencies, multilateral organizations, and recipient countries. We also highlight promising research questions that can be analyzed with the multi-bi data. In a first empirical application of the data, we analyze four suggested donor motives for earmarked aid at the donor-recipient level. Contrary to donor claims, we find that earmarked aid and bilateral aid target the same recipients. We also find evidence that some donors use earmarked aid to bypass recipient countries with weak governance. Overall, our explorative analysis suggests that earmarked aid serves many purposes and that donors use it in different ways. This calls for more fine-grained research on the reasons and implications for earmarked aid.
\end{abstract}

Key words: Foreign aid; aid delivery channels; earmarked aid; delegation; principal-agent; collective principal JEL codes: F35, F53, F59, 019

Acknowledgments: The authors thank Tilman Brück, Axel Dreher, Andreas Fuchs, Hinnerk Gnutzmann, Elena McLean, Alexandra Rudolph, Rainer Thiele, Felicity Vabulas, participants at the Beyond Basic Questions Workshop 2015 (Hannover), the Conference on Development Economics Group of the German Economic Association 2015 (Kiel), and the Political Economy of International Organizations Conference (Salt Lake City, UT) for helpful comments on previous versions of this paper, Franziska Volk and Sven Kunze for valuable research assistance, and Jamie Parsons for proofreading earlier versions of this article. Both authors gratefully acknowledge support from the Swiss Network for International Studies. 


\section{The rise of earmarked funding and its consequences}

Over the last two decades, donor governments have increased the share of the foreign aid they provide as earmarked funding to multilateral organizations. From negligible amounts in the 1990s, earmarked aid has risen to roughly USD 20 billion in 2012 - representing almost half of multilateral aid and about a quarter of bilateral aid (Figure 1). Earmarked aid, which has alternatively been referred to as multi-bi aid, non-core, or restricted funding, is implemented by a multilateral development organization in the sector, country, or region stipulated by the donor. ${ }^{1}$ As a hybrid between bilateral and multilateral channels, it combines the advantages of the two 'traditional' ways of providing aid: it provides donors with the opportunity to use the expertise and implementing capacity of multilateral agencies while keeping close control over the use of funds. This makes earmarked aid an attractive tool for donor countries. From the perspective of the multilateral organization, earmarked aid reduces flexibility, interferes with the multilaterally-agreed agenda, and increases transaction costs.

[Figure 1 about here]

Academic research on earmarked aid and trust funds, the institutional vehicle in which earmarked aid is managed by the multilateral organization, has taken off only recently. While recent contributions improve our theoretical understanding of earmarked aid (Eichenauer and Hug 2015; Graham 2015; Bayram and Graham forthcoming), systematic evidence on many empirical issues related to earmarked aid is still scarce. For example, the implications of earmarked funding for aid effectiveness, donor coordination, accountability, and recipient country ownership remain largely unassessed. This is partly due to the lack of high-quality data on earmarking over time. The new multi-bi aid data introduced in this paper will advance this emerging strand of the aid literature by offering a longer time-series, more precise information about the international development organizations receiving the funds, and, for individual aid activities, information about the earmarking type and the intensity of earmarking.

Using the new data, we graphically illustrate the temporal, geographical, and sector use of earmarked aid and provide a first empirical application that analyzes the allocation of earmarked aid by donor governments across recipient countries. Beyond the question addressed in this paper, the data allow researchers to tackle questions such as the rise of earmarked aid and the (differential) involvement of multilateral organizations, and to test theories about allocation patterns of earmarked aid across sectors and recipient countries.

The remainder of the paper is structured as follows. Section 2 introduces the data. Section 3 explores the data from the perspective of each actor affected by earmarked funding, namely donor countries and their aidproviding agencies, multilateral organizations, and recipient countries. In section 4, we summarize the theoretical explanations for earmarked aid and provide a first application using the multi-bi aid data. Section 5 concludes.

\section{Introducing the new multi-bi aid data}

\footnotetext{
${ }^{1}$ Multi-bi or earmarked aid refers to "voluntary external assistance from donors for a multilateral agency which is supplementary to core membership contributions and which is earmarked for specific purposes" (OECD 2005: 102).
} 
The multi-bi aid data allow us to systematically track the rise of earmarked aid and to refine our understanding of the most involved donors, multilateral organizations and recipient countries. After describing the three parts of the dataset, we demonstrate its key advantages over existing datasets but also its limitations, and discuss the research questions that can be addressed.

\subsection{The three components of the multi-bi aid dataset}

The multi-bi aid data are an original dataset on earmarked aid to multilateral organizations. They allow researchers to track earmarked aid across donors, multilateral organizations, and sectors over the 1990-2012 period. The data are based on the Creditor Reporting System (CRS) of the OECD's Development Assistance Committee (DAC) and improved through expert coding. As documented in the codebook (Eichenauer and Reinsberg 2014), the multi-bi data extends, refines, and corrects information on the multilateral organizations receiving earmarked aid and provides new variables on earmarking depth and intensity. The dataset consists of three components.

Component 1 of the dataset includes the 290 multilateral institutions with permanent organizational structure mentioned in donors' project descriptions (identified by a unique parentID). In addition, component 1 includes all institutional sub-structures (i.e., trust funds; identified by a unique childID) at multilateral organizations that are established under the institutional law of the host organization. We coded the two levels of institutions based on information from multilateral agencies' website and from donor-provided project information.

Component 2 is at the level of the aid activity. For each aid project, it contains information about the multilateral organization (parentID) and, where available and applicable, the institutional sub-structure inside the organization (childID). Component 2 also includes variables containing information about the earmarking intensity or depth. The earmarking intensity is evaluated based on the mandate of the multilateral organization. Earmarking can relate to geography, sector, and specific institutional arrangements (e.g., a requirement to use the donor's own staff for a dedicated operation) and be of the soft or strict type. For example, for a global multi-purpose organization such as the United Nations (UN), soft earmarking in the geographical dimension designates a specific region (e.g., Sub-Saharan Africa), whereas strict earmarking targets a specific country. Similarly, in sector earmarking, donors may specify a broad theme (e.g., maternal health), or a specific project (e.g., distribute basic health kits to vulnerable rural children). Through the childID, the multi-bi aid data provide some insight into the institutional arrangements through which multilateral agencies receive earmarked funding (see also, Component 1). For the United Nations Development Program (UNDP), for example, we identified six thematic trust funds (TTFs), covering development themes such as democratic governance (DGTTF), environment and energy (EETTF), gender (GTTF), HIV/AIDS (HATTF), crisis prevention and recovery (BCPR), and poverty reduction (PRTTF). These trust funds receive a childID in our data that acknowledges the institutional dependence on the multilateral parent organization, coded as parentID. Whenever the project description does not mention a multi-donor trust fund, the earmarked activity is considered a single-donor endeavor. Thus, the data might over-represent single-donor trust funds. 
Component 3 aggregates component 2 across multilateral organizations to obtain an annual panel of donors' use of earmarked aid. This component allows researchers to trace all earmarked flows in the system, including the ones provided by multilateral institutions without implementing capacity (termed 'pass-through multilaterals' in Reinsberg et al. 2015a; referred to as global or vertical funds in policy discussions) to multilateral organizations with implementing capacity. The largest such funds without implementing capacity are the Global Alliance for Vaccines and Immunization (GAVI), the Global Environment Facility (GEF), and the Global Fund to Fight Aids, Tuberculosis, and Malaria (GFATM). As these 'pass-through multilaterals' provide earmarked aid to multilateral organizations on behalf of the bilateral donors, we repatriate their earmarked aid to the bilateral donors that are the original providers of the earmarked aid (Reinsberg et al. 2015a: 535).

For further details, we refer readers to the codebook (Eichenauer and Reinsberg 2014). The multi-bi aid data can be obtained through our websites and the AidData portal (http://aiddata.org/donor-datasets).

\subsection{The value added of the multi-bi aid data}

The new multi-bi aid data have several advantages over the CRS data on which they are based. First, the new data extend the temporal availability of information on the multilateral channel. Figure 2 plots the number of earmarked activities in the two datasets, illustrating that the CRS data miss out all flows prior to 2005, the year the OECD/DAC first asked donor countries to report the channelcode variable.

[Figure 2 about here]

In addition, information on the multilateral channel is more reliable in the multi-bi aid data. Based on handcoding information available in those individual project descriptions, we removed coding ambiguities, imprecisions, and reporting errors. We identified previously unreported earmarked aid activities and, where the channelcode was already available, verified the information on the multilateral implementing channel. Unlike the CRS data, the multi-bi aid data offers parentID and childID and not just one channelcode and hence offer more flexibility to researchers. Our data ensure temporal continuity in the channels considered as multilateral. As we explain in the codebook, this is not the case in the CRS data. Last but not least, our data include detailed information on earmarking intensity, which offers the opportunity to study the number and type of earmarking and their variation across multilateral agencies.

\subsection{Potential applications using the multi-bi aid data}

The multi-bi aid data allow researchers to study a wide array of research questions related to earmarked aid in the areas of international relations and foreign aid. First, the extended coverage of the data allows researchers to study the origins and dynamics of earmarked funding over the past two decades: Which donors and which multilateral organizations were first movers, and which ones followed the trend? Did earmarked aid serve different purposes in different time periods? In what circumstances do donors prefer single-donor over multidonor trust funds? Reinsberg et al. (2015b) develop and test a theory of donors' participation decisions in World Bank trust funds of varying size of membership.

Second, the literature on the determinants of donor generosity (e.g., Fuchs et al. 2014; Fuchs and Richert 2015) lacks an analysis of the factors influencing the provision of bilateral, earmarked and multilateral aid. An 
important question is whether earmarked aid cannibalizes other forms of aid. In a first analysis, Reinsberg et al. (2015a) find earmarked aid to be additional but refined analysis focusing on individual donors and multilateral organizations is still needed.

Third, the literature on the allocation of earmarked aid across multilateral organizations, recipient countries, and sectors is still in its infancy. Eichenauer and Hug (2015) provide descriptive evidence that better-evaluated multilateral organizations receive more earmarked and more multilateral 'core' aid while Eichenauer and Knack (2016) and Wagner (2016) compare the allocation of World Bank trust funds to the one of the International Development Association (IDA) and to bilateral aid. Eichenauer and Knack (2016) find evidence that trust fund aid is motivated by strategic donor interests, especially aid to those types of trust funds over which donors have more control. This finding suggests that earmarked and bilateral aid are used as differently as claimed by donor countries. Also, a recent strand of the aid allocation literature emphasizes donors' strategy of bypassing recipient governments with low levels of governance by using aid delivery channels other than bilateral aid (e.g., Bermeo 2011; Dietrich 2013; Knack 2014; Acht et al. 2015). It is an open question of which countries and circumstances earmarked aid rather than NGOs or other non-state actors are used to bypass the recipient government.

Fourth, the extended time period, refined information on the multilateral channels and new information on the restrictiveness of earmarking can be used to study the implications of earmarked aid for multilateral organizations. Examining the case of the World Bank, Reinsberg (2016) finds that trust funds increase transaction costs and expedite institutional fragmentation in multilateral organizations. Some open questions are: What determines whether a multilateral organization receives (soft or strict) earmarks and whether these earmarks apply to the geographic, thematic, or institutional dimensions? Will inefficient organizations stop being funded (multilaterally) and survive on earmarked funding alone? A related issue that has received much recent scholarly attention refers to the autonomy of multilateral agencies (e.g., Haftel and Thompson 2006; Hawkins et al. 2006; Goetz and Patz 2016). An important issue is whether earmarking affects multilaterals' ability to pursue their independent agendas. The multi-bi aid data may be used to analyze the overlap in recipient countries and sectors between earmarked, bilateral and multilateral aid to shed light on this question. Fifth, the efficiency and effectiveness of earmarked aid are important questions. For these questions in particular, it is important to consider the institutional forms through which earmarked aid is provided, which can range from single-donor trust funds to (large) multi-donor funds. An important question is how the institutional fragmentation within multilateral organizations brought about by earmarked aid affects fragmentation and delivery in recipient countries.

We address some of these questions graphically (section 3) and in a first multivariate analysis (section 4) but note that there is ample room for more systematic analysis.

\subsection{Limitations}

Given that the multi-bi aid data are based on the CRS data, most of the same limitations apply. First, data quality hinges on the quality of donors' own reporting. We coded additional information from the project descriptions and found reporting quality (of project descriptions) to be heterogeneous across donors and over 
time. Despite our best efforts, not all earmarked aid activities may be identified. In this case, the true significance of earmarked aid is underestimated, especially in the earlier years, when reporting quality was lower (OECD 2010: 38). ${ }^{2}$

Moreover, the multi-bi data cover few sources of aid other than the group of OECD/DAC donors. While we have coded the information reported by Arab donors and by global funds, which are partly financed by private sources, there is no information on the earmarked aid flows from other non-OECD countries or from private sources of aid. We also miss another source of earmarked aid: 'counterpart contributions or 'non-core local contributions,' which refer to developing countries' own resources to cover part of multilateral agencies' technical assistance (UN 2012: 3). By triangulation from other sources, such as the World Bank trust fund databases and UN budget reports, we assess that non-DAC sources of earmarked aid are negligible, though they may have become more significant over the last few years (e.g., Eichenauer 2015, UN 2012).

\section{Exploring key trends in the use of earmarked aid}

The multi-bi aid data allow us to study the role of each actor involved in the process of earmarking over time. First, we look at the financiers of earmarked aid, donor countries and their aid-providing agencies. We then shed light on the international development organizations to which donors delegate the aid for implementation and disbursement to the targeted beneficiaries. Lastly, we focus on the ultimate beneficiaries of earmarked aid: global public goods and recipient countries.

\subsection{Donor countries}

Figures 1 and 3 display the upward trend in earmarked funding in absolute and relative terms, respectively. Following a rapid growth beginning in the 2000s, earmarked aid flows reached about USD 20 billion in 2012. Earmarking seems like the 'best of both worlds' for a donor government, combining the benefits of multilateral delegation with, as in the case of 'pure' or traditional bilateral aid, the control over the allocation of resources to specific projects. Puzzlingly, donors' use of earmarked aid is all but homogeneous. Figure 3 depicts the average use of earmarked aid by the 23 DAC donors in our sample for the years 2006-2012, when earmarked aid became substantial for many donors. The contrast between donors is stark: while Korea spent only three percent of its aid budget as earmarked aid, Canada provided almost a quarter of its total aid envelope as earmarked aid.

[Figure 3 about here]

Figure A1 in the Online Appendix explores donor heterogeneity in the use of earmarked funding over time. ${ }^{3}$ More specifically, we divide each donor's earmarked aid budget by its remaining bilateral aid budget (dubbed

\footnotetext{
${ }^{2}$ The OECD/DAC notes discusses the quality of the CRS data and its coverage ratio here: http://www.oecd.org/dac/stats/crsguide.htm (accessed October 18, 2016).

${ }^{3}$ The Online Appendix is available on the website of the Review of International Organizations.
} 
'pure' bilateral aid). This captures the intensity of a donor's use of earmarked aid and is comparable across donors and donor groups. We compare the average share of earmarked aid in the total aid budget for a given donor within each of four time periods (1990-1995, 1996-2001, 2002-2007, 2008-2012), three of which consist of six years and one of five years. For tractability, only the largest aid donor countries and the largest donors of earmarked aid are represented individually, while we group the remaining donor countries together. Donors are put into groups based on their geographic proximity and/or based on similarity in the evolution of their shares of earmarked aid. For example, we group the large aid donors Japan, Germany and France together because they have all used earmarking to a small extent.

Figure A1 shows that earmarked aid has increased as share of total aid budgets in all donor countries and groups, which is in line with the aggregate trend in Figure 1. In Germany and the Netherlands, there is a reduction in the share of earmarked aid from the second-to-last (2002-2007) to the last period (2008-2012), while in most donor countries/groupings, the share of earmarked funding doubles between these two periods. Within each of these time periods, there is substantial variation in the average share of earmarked aid provided across donors. During the 1996-2001 period, the Dutch government already provides earmarked aid equivalent to $18 \%$ of its 'pure' bilateral aid budget, while the average Nordic country provides $12 \%,{ }^{4}$ and France, Germany, and Japan earmark hardly any aid at all.

Figure 4 explores in more detail which donor countries lead the earmarking trend. The graph compares the relative importance of each donor country in total earmarked aid for two time periods of almost equal length (1990-2001 and 2002-2012). The donor countries to the left of the dotted diagonal line increase in (relative) importance over time while those to the right decline in relative terms. The slope of the solid line representing the line of best fit is less steep than the slope of the diagonal line and has a positive intercept, which implies that earmarked aid has become an established aid instrument for a majority of donor countries over the past decade. Bubble sizes are determined by donors' total aid budget in the second time period (2002-2012) and represent their importance as aid providers in absolute terms. The Netherlands, Norway, and Sweden are the leading donors in the 1990-2001 period, providing, respectively, 25, 15, and 14\%, and thus together more than half of all earmarked funding in the period. The United Kingdom and Australia provide around $5 \%$ each in the first time period. Detailed analyses show that these five donors, Canada, and Denmark started providing earmarked aid in the early 1990s. Although the three 'pioneer' donors remain among the ten most important providers in the second time period, the United Kingdom and the U.S. are the most important donors in the second time period, providing 10 and $9 \%$ of earmarked funding respectively. The graph also shows that the earmarking of aid becomes much more common in the second period and, consequently, is no longer dominated by a small number of donors. It is noteworthy that none of the largest aid donors is an early adopter of earmarked aid and that some large donors remain marginal (Germany and France), while others become important actors (the United States and the United Kingdom).

[Figure 4 about here]

\footnotetext{
${ }^{4}$ In the 1996-2001 period, Denmark is an outlier in the Nordic group, providing only around 1.5 percent of its 'pure' bilateral aid as earmarked aid.
} 
In policy debates, the argument is often raised that smaller donor states with less (formal and informal) influence in a multilateral organization should be the most likely to use earmarked funding to make the organization work in their preferred issue areas. A World Bank evaluation notes that the majority of donor countries use earmarked funds to influence the World Bank (IEG 2011). But although the data show that some smaller states with generous aid budgets have spearheaded the rise of earmarked funding and that some large donors have used earmarked funding to a small extent even in recent years, this pattern is not observed across all small and large states. We review related theories for donors' choice of earmarked aid and other aid delivery channels in section 4.

We now turn to examining the aid-providing institutions within a government administration and first analyze whether national ministries, departments and other agencies use earmarked aid to make a foray into bilateral aid provision. There is no such evidence. All government agencies reporting earmarked aid also provide bilateral aid. Next, we investigate the OECD's (2011: 18) claim that "there are many examples of dispersed decision-making" regarding multilateral core (unearmarked) contributions and earmarked aid to the same multilateral organization. Unfortunately, we cannot study this claim directly as we lack information about the donor agency responsible for unearmarked funding to each of the 290 multilateral development organizations we identified. Instead, we analyze the national agencies that provide bilateral aid on which information is available in the CRS. We find that in almost all donor countries, the one or two government agencies that jointly disburse 55 to $100 \%$ of bilateral aid also jointly report more than $80 \%$ of a donor governments' earmarked aid.

Figure A2 illustrates the concentration ratio of national agencies providing bilateral and earmarked aid. Specifically, the bars show the ratio of two Herfindahl indices: the index for earmarked aid relative to the index for bilateral aid. ${ }^{5}$ Values above one indicate a more concentrated use of earmarked aid. With the exception of Korea, we find the provision of bilateral aid to be more dispersed than that of earmarked aid. The black circles indicate the average number of ministries, departments, and other agencies within donor governments that were engaged in the provision of earmarked aid in the period 2002-2012. In sum, the data suggest that the national lead aid agency/agencies are the first to use earmarked aid and are responsible for providing most of its volume.

The descriptive evidence in this section demonstrates the large heterogeneity in donors' use of earmarked aid, which warrants theoretical explanations and more systematic empirical analysis. The leader-follower figures suggest that smaller states pioneered the use of earmarked aid. This casts some doubt on the explanation that global trends in development cooperation led to the adoption of earmarked aid. At the same time, the creation of global funds is based on a shared desire among the donors to cooperate beyond existing multilateral organizations. Theories will need to be able to explain both of these observations.

\subsection{Multilateral organizations}

\footnotetext{
${ }^{5}$ We calculate the Herfindahl index as the sum of squared shares of a donor's agencies in the donor's total aid budget. Values thus range from $1 / N$ to 1 , where $N$ refers to the number of aid-providing agencies.
} 
Next, we take a closer look at earmarked aid from the perspective of multilateral development organizations. They are the first recipients and implementers of earmarked funds. ${ }^{6}$ The bars in Figure 5 show that in the years 1990-2012 between 4 and 26 multilateral organizations are reported as being first-time recipients of earmarked funding. ${ }^{7}$ There is no trend in the number of new organizations (identified through the parent/D) reported by donor countries. The bold line shows the increase in the total number of organizations reported as receiving earmarked aid in a given year. There is an accelerated increase in the number of receiving organizations between 2002 and $2007 .{ }^{8}$ The figure suggests that few organizations are involved at first but that earmarked funding has become widely accepted across multilateral organizations.

[Figure 5 about here]

We explore this pattern further by considering the market share of the UN, the World Bank, regional development banks, and other multilateral development organizations during the four different time periods used previously. ${ }^{9}$ There is surprisingly little variation in the relative importance of these groups of multilateral organizations over time, suggesting that there is not one multilateral organization that led the earmarking trend. Of the total earmarked funding, the UN and its sub-entities (i.e., funds and programs, and specialized agencies) receive around 50\%, the World Bank between 15 and 25\%, and the regional development banks less than $5 \%$ in all four time periods. The remaining multilaterals jointly receive between 20 and $28 \%$ of earmarked aid, despite the increasing number of multilateral organizations within the category 'other agencies'. In contrast to this aggregate analysis, there is substantial variation in the share of earmarked aid going to different multilateral organizations across donors within a time period and within donors over time. In the early 1990s, most donors provided the majority of their small amounts of earmarked aid to UN organizations and only the Netherlands, an early and relatively large provider of earmarked funding, was already engaged with the World Bank to a substantial extent. In the late 2000s, the World Bank received a greater share of every donors' earmarked aid than in the 1990s. In absolute terms, the Bank continued to receive the most substantial amount of earmarked aid primarily from three donors: the United States, the United Kingdom and the Netherlands. ${ }^{10}$

Finally, we examine the intensity of earmarking across multilateral agencies. For this purpose, we use the hand-coded information on earmarking of individual aid activities that is not available in the CRS data. Taking into account the mandate of the multilateral organization, a donor's contribution is earmarked if the funded aid activity is more specific than the mandate. The more specific the restriction, the stricter is the earmark on one or several of three dimensions: geography, sector, and specific institutional arrangements. Figure 6 shows the earmarking patterns for all donors, all multilateral agencies and all dimensions based on the number of earmarked aid activities in the 2002-12 period. The figure shows that institutional earmarking is rare, and that

\footnotetext{
${ }^{6}$ Most earmarked funds provided to multilateral organizations are pre-specified for specific countries, sectors, or focus areas but some money supports institutional capacity building, research on specific topics, or targets other programs and initiatives within a multilateral organization (see Eichenauer and Reinsberg 2014).

${ }^{7}$ We caution against over-interpreting the finding of a single year in the early 1990 s as solid evidence because problems of underreporting in this period were substantial.

${ }^{8}$ This might be due not only to the actual increase in aid-receiving organizations but also to improved data quality.

${ }^{9}$ No graphs are shown but they can be obtained from the authors upon request.

${ }^{10}$ The World Bank also receives substantial amounts of earmarked aid from the European Commission.
} 
geographic earmarking is most widespread. 85 per cent of earmarked aid targets one recipient country while almost all of the remaining earmarked aid is targeted to specific world regions. Given differences in the breadth of mandates, these figures only provide a first glimpse of the data, leaving the detailed analysis to future research.

[Figure 6 about here]

The empirical patterns in this section shed light on some important questions related to earmarked funding while raising interesting new questions. For example, the patterns demonstrate that the volume of earmarked aid has increased rather than earmarked funding being an entirely new phenomenon for the largest multilateral organizations. At the same time, the practice of earmarking has spread to other multilateral organizations. Section 2.3 highlights some of the many open questions regarding the implications of earmarked aid for the functioning, effectiveness, and efficiency of multilateral organizations.

\subsection{Recipient countries}

We now turn to the ultimate beneficiaries of earmarked aid. According to officials from national aid agencies interviewed by the Independent Evaluation Group (IEG), donor governments resort to earmarked aid when "bilateral aid is not an option" and there is a need "to fill gaps in the multilateral system" (IEG 2011: 5). One such gap is the financing of global public goods (e.g., the environment or global health), which are challenges that must be addressed beyond the multilateral development banks' country-based lending model. As a first check of donors' explanation for earmarked aid, we consider whether earmarked funding is more focused on global activities than bilateral aid and/or if it is allocated to different sectors. In contrast to donors' explanations, the political economy literature would emphasize donor interests in the use and allocation of earmarked aid. An overlap in the countries and sectors receiving bilateral and earmarked aid would be consistent with a political economy explanation.

In the following, all graphs use earmarked aid commitments provided by a donor country for purposes other than debt relief and humanitarian aid. Given their development perspective, recipient countries are arguably most interested in earmarked aid given for development purposes rather than relief from debt that has already been spent or humanitarian aid covering urgent and immediate needs in the wake of disasters and other crises. ${ }^{11}$ Figure 7 shows that for the most important providers of earmarked funding the share of earmarked aid for global purposes increases over time. European DAC donors are the exception; their already low share decreases over the time period. For the non-European DAC donors, the share is below $12 \%$ in all periods. We further find for most donors that the share of earmarked aid provided for global purposes is

\footnotetext{
${ }^{11}$ The concept of earmarking only partly carries over to the humanitarian realm: In some cases, agencies explicitly ask for specific supplies (i.e., shelters, equipment, or food); when donors provide such requested supplies, their contributions are earmarked by definition. In other cases, earmarked aid is donor-driven although for possibly distinct reasons that earmarked aid for development purposes. In the multi-bi aid data, $25 \%$ of earmarked aid activities are provided for humanitarian purposes and less than $1 \%$ is earmarked for debt relief. Almost all humanitarian aid or debt relief are earmarked for a specific country ( $89.7 \%$ and $89.5 \%$ respectively) and more than one third or fifth moreover has a sector earmark.
} 
slightly lower than the corresponding share for bilateral aid. The Netherlands, the United Kingdom and, in the 1990s, the European DAC donors and the United States provide a higher share of bilateral than of earmarked aid for global public goods.

[Figure 7 about here]

We explore in some detail at the annual level whether donors use earmarked aid to enter sectors not served through their bilateral aid but do not find any evidence to support donor officials' justification for the use of earmarked aid. ${ }^{12}$ Similarly, we do not find any evidence that donors use earmarked aid to engage in countries and territories where they do not have an own bilateral presence. ${ }^{13}$ While these observations are based on descriptive analysis only, they are in stark contrast to the observation of the OECD (2011: 7), which notes that "there is growing pressure on the multilateral system to deliver in countries and regions where bilateral donors are exiting or unable to intervene." Therefore, qualitative evidence about donors' strategic composition of aid modalities and more rigorous data analyses of the differences in the allocation of donors' bilateral and earmarked aid in terms of sectors, countries, and aid modalities is needed. In the first multivariate application of the multi-bi aid data, section 4 tests for allocation similarity between earmarked and bilateral aid.

Besides the lack of mechanisms for financing global public goods and the use of earmarked aid to venture into countries where bilateral aid is not an option, donors also note that the multilateral system falls short of having adequate institutions to respond "to emergencies such as natural disasters, disease outbreaks, and the end of armed conflict" (IEG 2011:5). We first examine whether country-specific earmarked funding has indeed been allocated to post-conflict countries to a larger extent than bilateral aid. Figure 8 shows the absolute increase in earmarked funding to post-conflict countries - defined as countries recovering from war over the past five years - from around USD 5 billion in the 1996-2001 period to USD 18 billion in the last time period (2008-2012). In the years 2006-2012, the share of country-specific earmarked aid provided to post-conflict countries by all donor countries and groups was higher than that provided as bilateral aid (Figure A3). This suggests that donors choose earmarked aid as an aid modality in particular when engaging in high-risk contexts such as post-conflict countries. A replication of figures 8 and A3 for countries in conflict gives similar results except that the number of states in conflict and the absolute aid amounts provided are higher (around USD 34 billion for 2008-2012).

[Figure 8 here]

Another group of countries often mentioned as beneficiaries of earmarked aid are fragile states (OECD 2010; IEG 2011) and countries with low quality of governance (Dietrich 2013; Acht et al. 2015; Dietrich 2016). It has been shown that donors use 'non-state' aid that includes earmarked aid to circumvent weak recipient country

\footnotetext{
${ }^{12}$ We used CRS sector codes at the finest level of disaggregation (5-digit purpose code).

${ }^{13}$ We tried several different thresholds to define a bilateral presence in a country or sector, e.g., annual commitments above 10,000 USD or 100,000 USD, more than three activities, or combinations of these criteria. These alternative operationalizations do not affect the conclusion that earmarked aid supports countries or sectors that already benefit from bilateral aid.
} 
systems. We define a country as fragile or weakly governed if its governance score (according to the ICRG index on political stability, and, for missing values, the World Bank Governance Indicators) is in the lowest quintile and assert that, while there is some overlap with (post-) conflict countries, around half of fragile countries are not (post-) conflict countries in any year. The share of earmarked aid going to fragile countries has increased over time to reach between 40 and $50 \%$ for all individual donors and donor groups in the last period. ${ }^{14}$

We end the descriptive analysis by analyzing the claim that also not explicitly humanitarian earmarked aid is used to respond to the occurrence of natural disasters in developing countries. While there is indeed some comovement in the time series on total disaster damage and earmarked aid (for the 2002-2006 period), or between disaster occurrences and earmarked aid (for 1992-2001), it appears that earmarked aid overall follows a much smoother upward trend than the disaster series, which fluctuate between years. A potential relationship between disaster occurrence and non-humanitarian earmarked aid is better explored in a multivariate regression framework, where other factors can be held constant (section 4). The above figures shed some light on the usage of earmarked aid. We find that over the past decade, donors have concentrated their earmarked aid on fragile states and countries recovering from violent conflict.

This above section illustrates the wealth of information available in the multi-bi aid data by highlighting patterns in earmarked funding for donor governments and their aid-providing agencies, multilateral development organizations, and recipient governments. Further, we suggest avenues for future research on each of the actors individually and on their interactions. In the next section, we present theoretical perspectives on earmarked aid.

\section{Examining the determinants of earmarked aid: An explorative application using the multi-bi aid data}

The first application of the multi-bi aid data focuses on the donor countries as main providers of earmarked aid to multilateral organizations. Donors appreciate the flexibility offered by earmarked aid and have used it for many purposes. Therefore, a multivariate analysis is most adequate to simultaneously examine the main (quantifiable) explanations proposed by donor officials and in the literature. Thus, the goal of this section is not to primarily provide robust evidence for a particular theory but to offer empirical treatment to the main explanations proposed to explain donors' use of earmarked aid. We thus show results independent of statistical significance.

Two strands of the political economy literature consider principal-agent relationships that arguably influence donor motives for earmarked aid: the first one looks at the political economy within a donor country in which the donor government is the agent of its electorate, while the second considers the interaction between the donors as collective principal of the multilateral agent. In practice, both principal-agent relationships are likely to influence donors' choice of earmarked aid. Given the emphasis on different principal-agent relationships, the adequate unit of analysis differs. We choose to test the main arguments related to the principal-agent

\footnotetext{
${ }^{14}$ Figures are available from the authors upon request.
} 
relationship between the donor government and the electorate in donor countries. Our application can thus piggy-back on the developed literature about the choice of aid delivery channels. Moreover, the time horizon in which donors make their aid allocations is relatively short while changes to multilateral aid and governance must be considered in the longer term, which makes statistical analysis more challenging.

\subsection{Two principal-agent views on donors' motives for earmarked aid}

A first perspective on a donor's choice of earmarked aid focuses on the principal-agent relationship between the donor government (the agent) and the domestic electorate (the collective principal). The allocation of the bilateral aid budget across recipient countries, sectors, or themes, and the choice of the delivery channel are made under several considerations, which include budgets or existing country offices. From a political economy perspective, a key goal of the government is to be perceived as competent, while a bilateral aid agency seeks to claim responsibility for successes while shifting the blame for bad outcomes to others. We argue that earmarked aid appears to be an excellent way out of this dilemma. In some contexts, the risk of project failure is high so that donor governments prefer not to commit to projects alone but to share the risks with other donors. Contexts in which risk-sharing benefits are most important are post-conflict situations or countries with low governance quality. Similarly, the benefits of risk-sharing are high in post-disaster settings. In these situations, donors can claim that there are no adequate multilateral response mechanisms in these situations (IEG 2011; Reinsberg et al. 2015b).

The previous literature has also argued that in weakly governed countries donors seek to deliver aid through entrusted channels such as non-governmental and multilateral organizations (e.g., Dietrich 2013; Knack 2014; Acht et al. 2015). In addition, there is evidence that weak governance and donor characteristics interact for the choice of aid delivery channel: Acht et al. (2015) find that the economic self-interest of donors in recipient countries weakens donors' rationale for bypassing the government while Dietrich (2016) shows that the share of 'bypass' aid a donor provides in low-governance countries interacts with the political economy in donor countries. Specifically, the market-orientation of donors' economies, such as their stance on outsourcing public service delivery domestically, positively correlates with the degree of 'bypassing' recipient governments in weak-governance countries. Beyond earmarked aid being included in the category of bypass aid, one important reason for using international organizations is to avoid engaging directly with the recipient country: when using earmarked aid donors can transfer liability to the implementing agency. Anecdotal evidence collected by the authors in interviews for other research articles on earmarked aid suggest that in a number of cases multilateral agencies were held accountable for the loss of assets. This is in line with the expectation of the political economy perspective.

Most directly, a donor government is influenced by the public opinion of the electorate. Eichenauer and Hug (2015) provide some argument for a relationship between bilateral aid and public opinion, expanding Milner's (2006) argument that donor governments use multilateral aid to signal the depoliticized, developmental use of foreign aid to skeptical domestic publics. Earmarked aid might allow donor governments to pocket the political benefits of low liability while remaining in the driver's seat regarding the allocation and use of the aid provided to the multilateral organization. Given the lack of panel data on public opinion, we are unable to test this argument in a satisfying way. 
In sum, the political economy of donor countries would suggest that earmarked aid is the ideal tool for solving the dilemma between sharing in development successes and responding to humanitarian duty while keeping control over the use of the aid and being able to shift the blame for undesired outcomes.

A second political economy perspective considers the principal-agent framework between a set of donor countries that forms the collective principal and delegates the conduct of development programs to a multilateral agent (see, e.g., Nielson and Tierney 2003; Hawkins et al. 2006; Copelovitch 2010). According to this literature in International Relations, the rationale for delegation mainly rests on informational advantages of the multilateral agency, burden sharing, and the possibility of acting collectively and altruistically on public goods (e.g., Milner 2006; Schneider and Tobin 2011). If the multilateral agency does not have the same preferences as the principal and holds private information, the agent is able to deviate from the preferred policy of the principal - a situation commonly referred to as agency slack. Principals can mitigate such slack through various control mechanisms such as earmarked funding. Sridhar and Woods (2013) provide evidence that donors created the Global Fund to Fight Aids, Tuberculosis, and Malaria to reorient the programmatic priorities at the World Health Organization. In a similar vein, Reinsberg et al. (2015a) argue that the rise of earmarked funding is associated donors' dissatisfaction with the performance of the multilateral system. Graham (2016) argues that voluntary unearmarked funding is an established feature of the multilateral system that reflects a situation in which donors agree about policy but not the budget. In contrast, earmarked contributions are the result of divergent preferences on both substance and finance. She also shows that earmarked aid is used mostly by donors that want to broaden an organization's activities beyond its mandate. Eichenauer and Hug (2015) propose a principal-agent model to explain donors' heterogeneous use of multilateral, earmarked, and bilateral aid, showing that the governance rule at the international organization, heterogeneity in donor preferences, concerns about aid effectiveness, but also domestic constraints interact in determining donors' choice of aid channel. In the EU context, principal-agent relationships are even more complex: Michaelowa et al. (2016) argue that when the European Commission (EC) engages in trust funds managed by other multilateral organizations and thus becomes their proximate principal, the EC earmarks to reassure member states, the ultimate principals, that their salient preferences are being addressed.

In summary, this strand of the literature on the relationship between donors and the multilateral organizations offers at least two central insights about the donor motives for using earmarked aid. First, the extent of perceived agency slack affects a donor's willingness to use earmarked funding. Second, preference heterogeneity among the donor countries that fund and govern the multilateral agent may lead 'like-minded' donors to engage in 'minilateral' cooperation to advance specific policies via earmarked aid.

\subsection{Research design}

We construct an unbalanced triadic panel dataset in which the main dependent variable is (logged) aid commitments from donor country $i$ to recipient country $j$ in year $t$. We use all dyadic observations with a nonzero aid flow (either bilateral or earmarked). The main sample comprises the 23 OECD/DAC donor governments and up to 158 recipient countries over the period 1990 to 2012, although we consider various sub-periods based on data availability of covariates and theoretical arguments about changes in aid allocation behaviors. 
Our main dependent variable is the natural logarithm of earmarked aid commitments for purposes net of debt relief and humanitarian aid, which is line in with the descriptive analysis of earmarked aid from the perspective of recipient countries (section 3.3). Aid commitments are commonly used in aid allocation studies because donors exert full control only over commitments, while aid disbursements also depend on the recipient countries and the implementing organizations. We also prefer using absolute earmarked aid amounts rather than earmarked aid as percentage of total aid because the latter implies assuming reallocation within fixed aid budgets. First evidence suggests that earmarked aid is additional to the traditional aid channels (Reinsberg et al. 2015a), which implies that earmarked aid is not merely the result of reallocation within aid budgets. In robustness tests, we alternatively use the (logged) share of earmarked aid as of donor GDP and donor population, respectively. Our main results are not affected by these alternative ways of operationalization (see appendix tables $\mathrm{A} 1$ and $\mathrm{A} 2$ ).

Our explanatory variables of interest relate to the theoretical arguments that seek to explain the use of earmarked aid at the recipient-country level. While we ex ante do not find all of the proposed explanations equally convincing from a theoretical perspective, we develop quantitative measures for all of them to allow a 'neutral' assessment of the relative importance of different factors. Our first set of predictors tests the bypass story, which suggests that donor countries, in particular those with market-oriented political economies, circumvent recipient governments with weak governance by channeling their aid through non-state development actors such as multilateral organizations. As described in the appendix, we include a standardized measure of recipient governance and interact it with the binary indicator market-oriented donor economy. ${ }^{15}$ Dietrich (2016) derives the distinction between market-oriented donor economies and coordinated market economies from the 'Varieties of Capitalism' literature, one aspect of which is the extent to which public service delivery is outsourced domestically. ${ }^{16}$ We expect a negative coefficient for both variables, reflecting the expectation that all donors bypass weak governments but that market-oriented donors outsource aid delivery to a larger extent.

Second, we test for the impact of natural disasters in recipient countries. According to donor countries, earmarked aid is faster allocated and disbursed to disaster-hit countries than multilateral aid (IEG 2011: 5). Most disaster aid is earmarked for a specific recipient country and disaster. This allows donors to determine for each disaster and a country the amount and type of support rather than providing sufficient funding to an emergency fund prior to disasters. We include the one-year lag of the (logged) number of disasters in a recipient country. ${ }^{17}$

\footnotetext{
${ }^{15}$ Note that the constitutive term of the latter variable drops out due to donor fixed effects.

${ }^{16}$ Market-oriented donor economies are Australia, Canada, Ireland, New Zealand, the Scandinavian countries (Sweden, Norway, Denmark, and Finland), the United Kingdom, and the United States (Dietrich 2016).

${ }^{17}$ To allow for the possibility that disaster aid is committed in the year of the disaster occurrence, we replace the lagged number of disasters with its contemporaneous value in columns 3-8 of table 1 . The coefficient remains positive but insignificant.
} 
Third, we include a binary indicator that is one if a civil or international war took place in the recipient country in the past five years. For both variables, we expect a positive relationship with earmarked aid because postconflict status implies greater need but also difficult environments and greater risks for donors.

Fourth, we consider the allocation similarity of traditional bilateral aid and earmarked aid at the recipientcountry level. The binary variable bilateral presence indicates whether there are positive bilateral aid flows in a donor-recipient dyad. A positive coefficient would suggest allocation similarity while a negative value would indicate that the donor uses earmarked funding as a substitute to traditional bilateral aid. Based on our descriptive evidence presented above, we expect a positive coefficient.

In addition to these key predictors, we include common covariates at the recipient and donor level. Based on the aid allocation literature, we identify five sets of variables at the recipient level. First, recipient need is proxied by (logged) recipient GDP per capita and recipient population. Second, the quality of dyadic political relationships is accounted for by a dummy for a shared colonial history with the donor and UNGA alignment, which measures the distance between the ideal points of a donor-recipient pair based on their voting in the UN General Assembly. Third, recipient trade openness captures the importance of international trade for the recipient country and thus its potential dependence on the developed world. In line with the recent literature on aid channels, we do not include recipient-fixed effects (Dietrich 2013; Knack 2014; Acht et al. 2015). Given that the quality of governance in recipient countries is highly persistent, little variation in the variables of interest would be left if recipient-fixed effects are included. Appendix table A1 shows that the main results are broadly robust the addition of recipient-country fixed effects.

All specifications include year-fixed effects to account for common shocks to (earmarked) aid budgets and international trends in development cooperation and donor-fixed effects that capture time-invariant donor heterogeneity. Some regressions also include common time-varying covariates at the donor level (e.g., Brech and Potrafke 2013; Fuchs et al. 2014; Fuchs and Richert 2015). Specifically, we include the donor's (logged) GDP per capita, its level of political globalization, its trade openness, its percentage of social expenditure in GDP, and its level of public debt as a percentage of GDP. These variables have been found to relate to donor aid budgets more generally (Fuchs and Richert 2015) and some of its subcomponents (Brech and Potrafke 2013).

\subsection{Empirical results}

First, our analysis seeks to ensure that the empirical specification replicates the findings from the recent literature on aid delivery channels. In the first two columns of Table 1, our dependent variable is (logged) aid commitments that bypass recipient-country institutions as defined in Dietrich (2016) and table A5. Bypass aid includes earmarked aid as one major category. To assure comparability, we follow Dietrich (2016) and focus on the 2005-2011 period. Bypass aid flows are available only since 2005, reflecting the lack of information on the aid delivery channel in the CRS data. The multi-bi aid data resolves this lack of a longer time-series for aid channeled through multilateral organizations. Consistent with theoretical expectations and the previous literature, market-oriented donors use bypass aid in countries with low-governance while there is no such 
effect for donors with coordinated market economies. The interaction effect is statistically significant at the one-percent level (column 1) and stays significant when donor controls are added (column 2).

For comparability of results, column 3 re-estimates the specification of column 1 for the 2005-11 period but replaces the dependent variable with earmarked aid. We confirm that the bypassing story (largely) holds for earmarked aid although statistical significance decreases. Substantively, a deterioration in governance by one standard deviation increases earmarked aid from market-oriented donor economies by $43 \%$ ( $p<0.01$ ). For coordinated market economies this (statistically non-significant) relationship is almost $14 \% .{ }^{18}$

While data on bypass aid before 2005 does not exist, our multi-bi aid data allows to test whether weak governance has been a motive for earmarked aid over a longer time period. The question of a sustained focus on governance is related to the debate in the aid allocation literature about whether donor selectivity with regard to governance has increased since the 2000s (e.g., Dollar and Levin 2006; Clist 2011; Wagner 2016). To test such claims, columns 5 and 6 analyze the years 2002-12. We again find statistically significant evidence that market-oriented donors use earmarked aid for bypassing recipients with low governance. In columns 7 and 8 , we use the full sample period for which earmarked aid is available. For this extended period, the interaction coefficient stays negative but is insignificant at conventional levels of statistical significance when donor controls are added in column 8.

Regarding the other explanations for donors' use of earmarked aid, we do not find evidence that disasteraffected recipient countries receive more (non-humanitarian) earmarked aid. While the coefficient has the expected sign, it is not statistically significant. Given that earmarked aid only includes the commitments for development purposes - excluding debt relief and humanitarian assistance - our test arguably is a rather strict one. In contrast, there is evidence that donors allocate earmarked aid to recipient countries in the aftermath of violent conflict. Although the coefficient is statistically significant only in columns 7 and 8 focusing on the 1990-2012 period, the coefficient is positive throughout the specifications for earmarked aid. Substantively, if a country had a violent conflict in any of the past five years, inflows of earmarked aid increase by $43 \%$ in average. $^{19}$

Our strongest and most novel finding pertains to the argument of earmarked aid allocation being similar to bilateral aid. In all regressions for earmarked aid, the coefficient on bilateral presence has an economic and statistically significant positive relationship with earmarked aid (columns 3-8). The effect is present irrespective of the time period, suggesting that allocation similarity with bilateral aid is a sticky feature of earmarked aid. According to column 8, the bilateral presence of a donor in a recipient country increases earmarked aid to this recipient country more than eight-fold $(p<0.01)$. These results support the descriptive evidence that donors do not use earmarked aid to venture into new countries. To the contrary, we find that if a donor is already engaged bilaterally with a recipient country, earmarked aid is used to reinforce countrylevel efforts. Note that our regression framework does not allow for causal interpretation of any of these findings.

\footnotetext{
${ }^{18}$ Computed based on column 3 as follows: For coordinated market economies, $100 *(\exp (-0.236)-1) *-0.65=13.6 \%$. For market-oriented donors, $100 *(\exp (-0.236-0.855)-1) *-0.65=43.2 \%$.

${ }^{19}$ Again using the exponential transformation on the coefficient of column $8: 100 *(\exp (0.363)-1)=43 \%$.
} 
We re-run the specifications of columns 3-8 in table 1, alternatively replacing the dependent variable with earmarked aid net of debt relief only (i.e., including humanitarian aid) and humanitarian aid. Independent of using the logarithm of earmarked aid net of debt relief or the logged share of donor's GDP, the coefficient on disaster remains statistically insignificant as in table 1 while the coefficient on post-conflict country is significantly positive throughout the equivalent of columns 5-8. As in table 1 , the interaction with donors' political economy is significantly negative in all columns while bilateral presence is significantly positive. The coefficient on recipient governance turns significantly negative in most columns. When we focus on the logarithm or the logged share of humanitarian aid, we find all coefficients to be statistically significant in the expected and previously found directions except for the number of natural disasters in those columns focusing on recent time-periods and having the logged share as dependent variable. ${ }^{20}$

Table 2 explores donor heterogeneity in the use of earmarked aid through a set of donor-specific regressions. We focus on the donors with the largest total aid budgets. Given that earmarked aid was negligible for most donors in the 1990s, we focus on the 2002-12 period. We find distinct patterns for the major donor countries but note that we cannot statistically compare the coefficients as they are from separate regressions. Given that we include only those donor-recipient relationships with positive bilateral or earmarked aid flows in a given year, the regressions consider only the allocation of aid across recipients but not the selection of aid recipients among all developing countries. The results suggest that for the United States, Sweden, and Canada the primary motivation is to bypass weak governments. All of these countries are market-oriented donor economies and thus influence the interaction effect found in table 1 . What is more, the coefficient on governance is negative for all coordinated donor economies (Japan, Germany, France and the Netherlands). Second, the relationship with the number of disasters is insignificant except for Germany, where the estimated coefficient is significantly negative. Third, some donors support post-conflict countries with significantly more earmarked aid, namely Japan, the United Kingdom, the Netherlands, and Norway. Finally, almost all major donor countries except Japan, use earmarked aid to target the same recipient countries as with bilateral aid flows. For Germany, the effect is insignificant, while for France no coefficient can be estimated due to insufficient variation in the variable.

While the main purpose of these regressions is to illustrate the usefulness of the multi-bi data and tables 1 and 2 provide only an exploratory analysis of the explanations for earmarked aid, we conduct some sensitivity analysis. We alternatively scale earmarked aid by donor GDP or by donor population to reduce the impact of large aid providers of aid on the estimated coefficients. Whether we express the relevant shares as percentages or use the natural logarithm thereof, results are similar. For reasons of consistency with the main estimation, we prefer the latter operationalization. Our main results are highly robust to these alternative dependent variables (see appendix tables $\mathrm{A} 1$ and $\mathrm{A} 2$ ).

Overall, we find that the bypass story holds for earmarked aid and suggest the novel finding that earmarked aid is allocated to similar recipients as bilateral aid. This stands in contrast to donors' claim that earmarked aid is used to venture into new countries that are not already covered bilaterally. One possible interpretation of this finding is that the allocation of earmarked aid is also driven by strategic donor interests. Through the

\footnotetext{
${ }^{20}$ Results are available upon request.
} 
donor-specific regressions, we provide insights into the differential motives of earmarked aid across donor countries. These results underpin the general conclusion from section 3 that earmarked aid serves many purposes and the finding that most donor countries allocate earmarked aid and traditional bilateral aid similarly. This section provided an explorative analysis of donor motives for earmarked aid. We leave it to future research to further analyze differences in donor motives, the allocation similarity between bilateral, multilateral and earmarked aid across areas of activities, and other research questions suggested in section 2.3, which can be tackled with the new multi-bi aid data.

\section{Conclusion}

This paper introduces an original dataset on earmarked or multi-bi aid. Multi-bi aid is a hybrid between bilateral and multilateral aid: it is provided by donor countries to multilateral development organizations and stored in trust funds before being implemented by the multilateral organization according to donors' prespecified priorities. The new data allow researchers to analyze earmarked aid over an extended period of time using refined information about the multilateral recipient and the earmarking stringency of individual aid activities with respect to the topic and the recipient country, region, or institution. The data consists of three components. The richness of information was illustrated through graphical analysis of the actors involved in earmarked aid, namely donor countries, multilateral organizations and recipient countries, and highlighted interesting data patterns. For each actor, we suggest research questions related to earmarked aid that researchers may theorize on and tackle empirically using the new data. Important questions in international relations regard the implications of earmarked aid for the relationship between donors to the same multilateral organization, between the donors, the multilateral organization and non-donating or small member states of the organization, and the competition between multilateral organizations. Scholars of foreign aid may want to study donors' heterogeneous use of earmarked aid, the allocation of earmarked aid across multilateral organizations, sectors, countries, modalities, and channels, and the effectiveness of this new aid type.

As a first application of the multi-bi aid data, we propose an explorative multivariate analysis of donors' motives for earmarked aid based on a triadic panel of 23 OECD/DAC donors and up to 158 recipient countries for the years 1990-2012 and shorter time period. We test four main explanations for the use of earmarked aid drawing from the literature on aid delivery channels and the principal-agent literature that focuses on the relationship between the electorate and the donor government. We argue that bilateral donor agencies favor control but are constrained in terms of capacities and their willingness to take risks. Donors are risk-averse because they face the predicament of proving their competence to the electorate via success stories while avoiding responsibility for failed projects. Donors thus prefer earmarked aid and other non-state aid delivery channels to (traditional) bilateral aid channels in high-risk contexts such as post-conflict and low-governance countries. Donors also claim to use earmarked aid in cases where bilateral aid is not an option. In contrast to these claims, we find strong evidence for complementarity between earmarked aid and (traditional) bilateral

aid at the recipient country level. Consistent with Dietrich (2016), we find that market-oriented donor economies use earmarked aid in low-governance countries. We find that some donors use earmarked aid to 
assist development in post-conflict countries but no evidence that donors systematically use earmarked aid after natural disasters.

This paper has raised many research questions about the actors, the motives, and the consequences of earmarked aid. The new multi-bi data introduced through graphical analysis and an explorative study allows to analyze some of these questions. Important research agendas include but are not limited the timing of the rise of earmarked aid and the pioneering donors and multilateral organizations, the implications of earmarked aid for multilateral organizations, and the efficiency and effectiveness of earmarked aid. We hope that the new multi-bi aid data contributes to furthering our understanding of the role of earmarked aid within the larger aid architecture. 


\section{References}

Acht, M., Mahmoud, T. O., \& Thiele, R. (2015). Corrupt governments do not receive more state-to-state aid: Governance and the delivery of foreign aid through non-state actors. Journal of Development Economics, 114, 20-33.

Bailey, M. A., Strezhnev, A., \& Voeten, E. (2015). Estimating dynamic state preferences from United Nations voting data. Journal of Conflict Resolution. Online first.

Bayram, A. Burcu, and Graham, Erin (forthcoming). Financing Global Governance: Explaining Donor Funding Patterns at International Organizations. Review of International Organizations.

Bermeo, S. B. (2011). Foreign aid and regime change: a role for donor intent. World Development, 39(11), 2021-2031.

Brech, V., \& Potrafke, N. (2013). Donor ideology and types of foreign aid. Journal of Comparative Economics, 42(1), 61-75.

Clist, P. (2011). 25Years of Aid Allocation Practice: Whither Selectivity? World Development, 39(10), 17241734.

Copelovitch, M. S. (2010). Master or servant? Common agency and the political economy of IMF lending. International Studies Quarterly, 54(1), 49-77.

CRED (2015). EM-DAT The International Disaster Database. Centre for Research on the Epidemiology of Disasters. www.emdat.be/database. Brussels: School of Public Health, Université Catholique du Louvain. Accessed April 2015.

Dietrich, S. (2013). Bypass or engage? Explaining donor delivery tactics in foreign aid allocation. International Studies Quarterly, 57, 698-712.

Dietrich, S. (2016). Donor political economies and the pursuit of aid effectiveness. International Organization, 70(1), 65-102.

Dollar, D., \& Levin, V. (2006). The increasing selectivity of foreign aid, 1984-2003. World Development, 34(12), 2034-2046.

Dreher, A. (2006). Does globalization affect growth? Evidence from a new index of globalization. Applied Economics, 38(10), 1091-1110.

Eichenauer, V. Z. (2015). Trust Funds: DAC Donors Contribute, Most Non-DAC Donors Don't. http://aiddata.org/blog/trust-funds-dac-donors-contribute-most-non-dac-donors-dont. Accessed October 2016.

Eichenauer, V. Z., \& Hug, S. (2015). The politics of special purpose trust funds. Unpublished Manuscript. Heidelberg: Heidelberg University. 
Eichenauer, V. Z., \& Knack, S. (2016). Poverty and policy selectivity of World Bank trust funds. Unpublished Manuscript. Heidelberg: Heidelberg University.

Eichenauer, V. Z., \& Reinsberg, B. (2014). Multi-bi aid: Tracking the evolution of earmarked funding to international development organizations from 1990 to 2012. Codebook. Zurich: CIS Working Paper No. 84.

Fuchs, A., \& Richert, K. (2015). Who is the development minister and does (s)he matter? Unpublished Manuscript. Heidelberg: Heidelberg University.

Fuchs, A., Dreher, A., \& Nunnenkamp, P. (2014). Determinants of donor generosity: A survey of the aid budget literature. World Development, 56, 172-199.

Goetz, K. H., \& Patz, R. (2016). Pressured budgets and the European Commission: towards a more centralized EU budget administration? Journal of European Public Policy, 23(7), 1038-1056.

Graham, E. R. (2015). Money and multilateralism: how funding rules constitute IO governance. International Theory, 7(1), 162-194.

Graham, E. R. (2016). The institutional design of funding rules at international organizations: Explaining the transformation in financing the United Nations. European Journal of International Relations, doi: $10.1177 / 1354066116648755$.

Haftel, Y. Z., \& Thompson, A. (2006). The independence of international organizations concept and applications. Journal of Conflict Resolution, 50(2), 253-275.

Hawkins, D. G., Lake, D. A., Nielson, D. L., \& Tierney, M. J. (Eds.). (2006). Delegation and agency in international organizations. Cambridge (MA): Cambridge University Press.

Hout, W. (2010). Governance and Development: changing EU policies. Third World Quarterly, 31(1), 1-12.

IEG (2011). An evaluation of the World Bank's trust fund portfolio: Trust Fund support for development. Washington D.C.: Independent Evaluation Group.

Knack, S. (2014). Building or bypassing recipient country systems: Are donors defying the Paris Declaration. The Journal of Development Studies, 50(6), 839-854.

Mayer, T., \& Zignago, S. (2006). Notes on CEPII's distances measures. Paris: CEPII's. Available from http://www.cepii.fr/anglaisgraph/bdd/distances.htm. Accessed May 2009.

Milner, H. (2006). Why multilateralism? Foreign aid and domestic principal-agent problems. In D. G. Hawkins et al. (Eds.), Delegation and agency in international organizations. New York: Cambridge University Press.

Nielson, D. L., \& Tierney, M. J. (2003). Delegation to international organizations: Agency theory and World Bank environmental reform. International Organization, 57(2), 241-276.

OECD (2014). General statistics. Paris: Organisation for Economic Co-operation and Development. Accessed June 2014. 
OECD (2013). OECD/DAC Creditor Reporting System. Paris: Organisation for Economic Co-operation and Development. Accessed September 2012 and July 2013.

OECD (2011). 2011 DAC Report on multilateral aid. Paris: Organisation for Economic Co-operation and Development.

OECD (2010). 2010 DAC Report on multilateral aid. Paris: Organisation for Economic Co-operation and Development.

OECD (2005). Managing Aid: Practices of DAC Member Countries. Paris: Organisation for Economic Cooperation and Development.

Pettersson, T., \& Wallensteen, P. (2015). Armed Conflict, 1946-2014. Journal of Peace Research, 52(4), 536550.

Reinsberg, B. (2016). The implications of multi-bi financing on international development organizations: The example of the World Bank. In T. Mahn, M. Negre, \& S. Klingebiel (Eds.), The fragmentation of aid: concepts, measurements and implications for development cooperation. Basingstoke: Palgrave McMillan, 185-198.

Reinsberg, B., Michaelowa, K., \& Eichenauer, V. Z. (2015a). The proliferation of trust funds and other multi-bi aid. In M. Arvin \& B. Lew (Eds.), Handbook of Foreign Aid. Cheltenham: Edward Elgar.

Reinsberg, B., Michaelowa, K., \& Knack, S. (2015b). Which donors, which funds? The choice of trust funds by bilateral donors at the World Bank. World Bank Policy Research Working Paper No. 7441. Washington D.C.: World Bank.

Michaelowa, K., Reinsberg, B., \& Schneider, C. (2016). Multi-bi Aid in European Development Assistance: The Role of Capacity Constraints and Member State Politics. Development Policy Review. doi/10.1111/dpr.12193.

Sarkees, M., \& Weyman, F. (2016). COW War Data, 1816 - 2007 (v4.0) - Correlates of War. Davis: UC Davis. http://cow.dss.ucdavis.edu/data-sets/COW-war. Accessed February 2016.

Schneider, C. J., \& Tobin, J. L. (2011). Eenie, Meenie, Miney, Moe? Institutional portfolios and delegation to multilateral aid institutions. University of San Diego, mimeo.

Sridhar, D., \& Woods, N. (2013). Trojan multilateralism: global cooperation in health. Global Policy, 4(4), 325335.

Teorell, J., Dahlberg, S., Holmberg, S., Rothstein, B., Hartmann, F., \& Svensson, R. (2013). The Quality of Government Standard Dataset. Version December 2013. University of Gothenburg: The Quality of Government Institute.

UN (2012). Analysis of funding of operational activities for development of the United Nations system for the year 2010. Report of the Secretary General. UN Department of Economic and Social Affairs. New York. 
Wagner, L. (2016). How do Earmarked Funds Change the Geographical Allocation of Multilateral Assistance? FERDI Discussion Paper No. 150. 


\section{Figures}

Figure 1: The evolution of earmarked aid

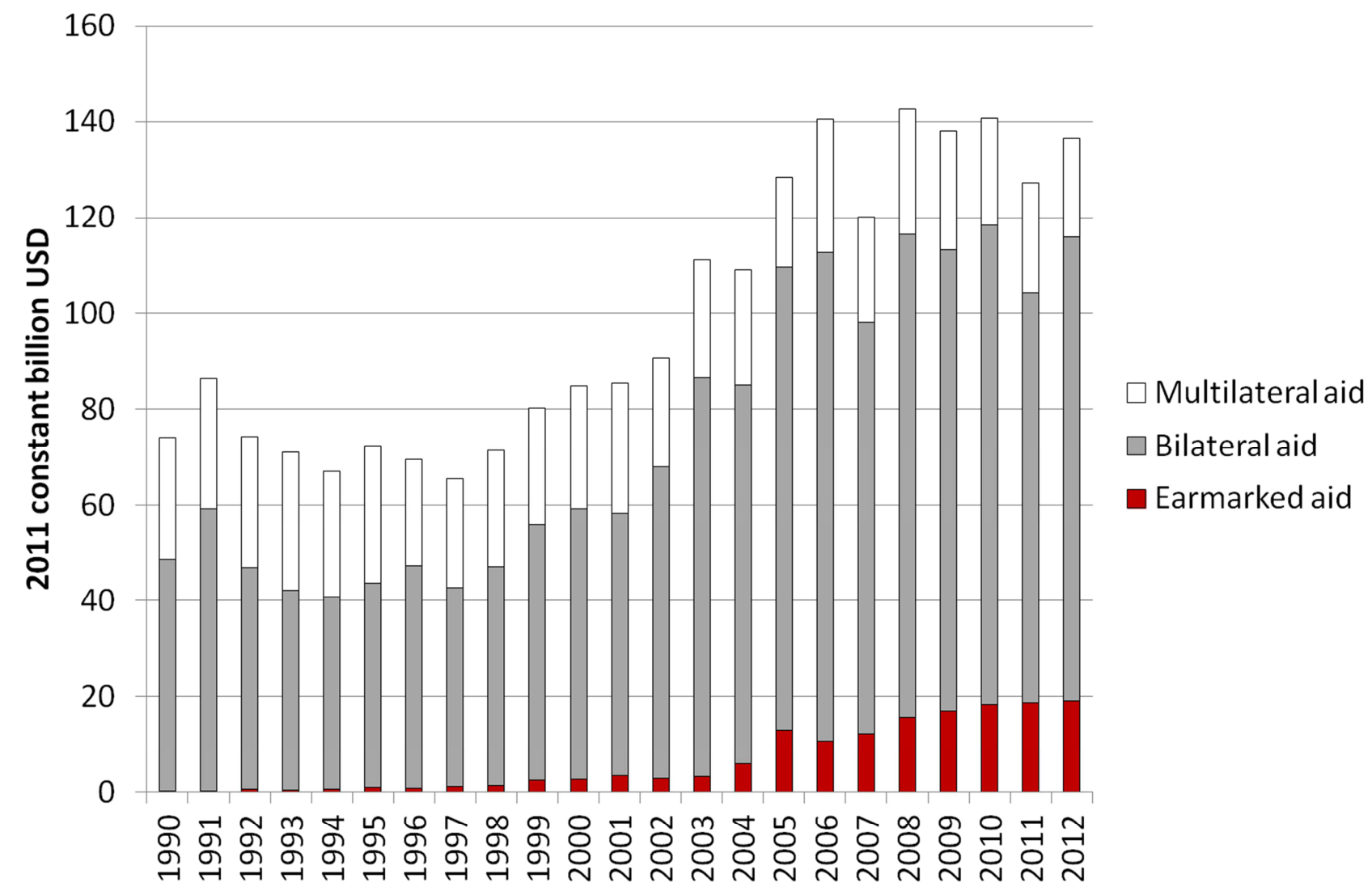

Notes: Earmarked ( $=$ multi-bi $=$ restricted $=$ non-core $)$ aid refers to any earmarked funds received by international development organizations. Multilateral aid consists of assessed contributions and unearmarked voluntary contributions to multilateral organizations. Traditional (= 'pure') bilateral aid is provided directly to recipient country governments or through intermediaries such as NGOs.

Source: reproduced from Reinsberg et al. (2015a) 
Figure 2: Comparison of coverage of the new multi-bi aid data and the Creditor Reporting System

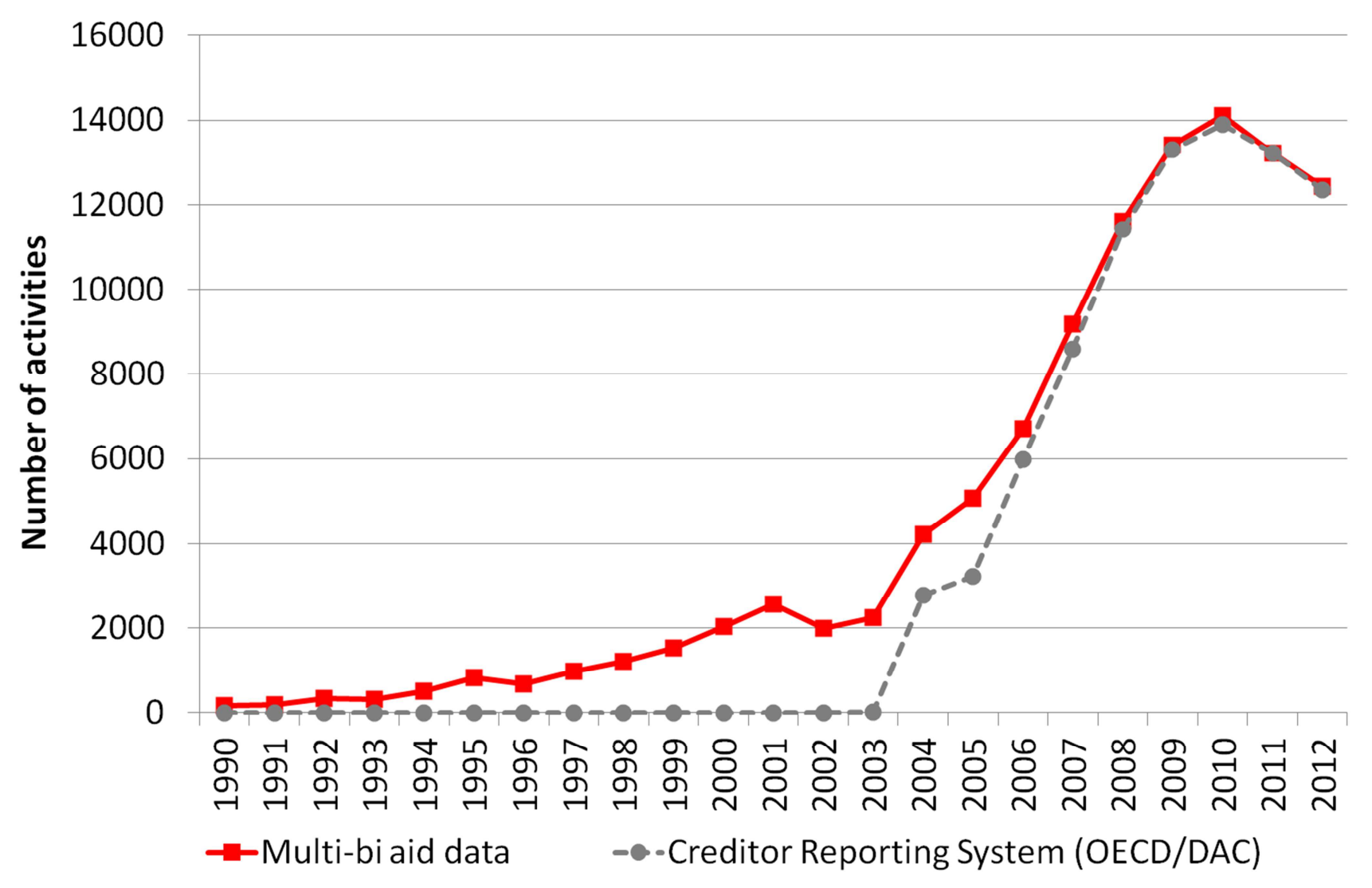

Notes: Comparison of number of earmarked activities between the new multi-bi aid data and the Creditor Reporting System (OECD 2013). The pattern for multi-bi aid commitments looks qualitatively similar. 
Figure 3: DAC donors' average use of different aid channels (2006-12)

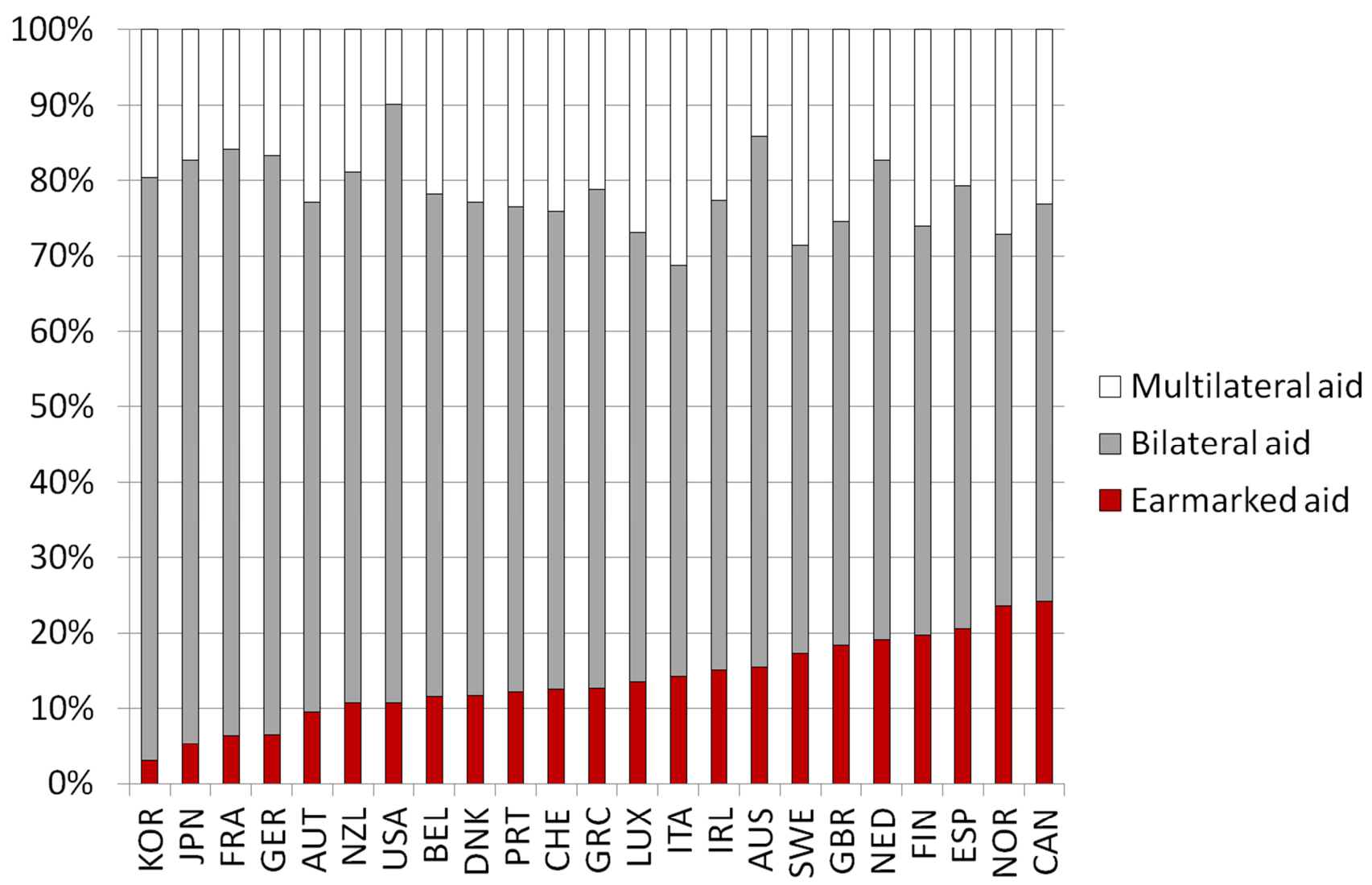

Notes: Average share of earmarked, multilateral and bilateral in total Official Development Assistance (20062012). The country abbreviations refer, from left to right, to South Korea, Japan, France, Germany, Austria, New Zealand, the United States, Belgium, Denmark, Portugal, Switzerland, Greece, Luxembourg, Italy, Ireland, Australia, Sweden, the United Kingdom, the Netherlands, Finland, Spain, Norway, and Canada. 
Figure 4: Leaders and followers in earmarked aid

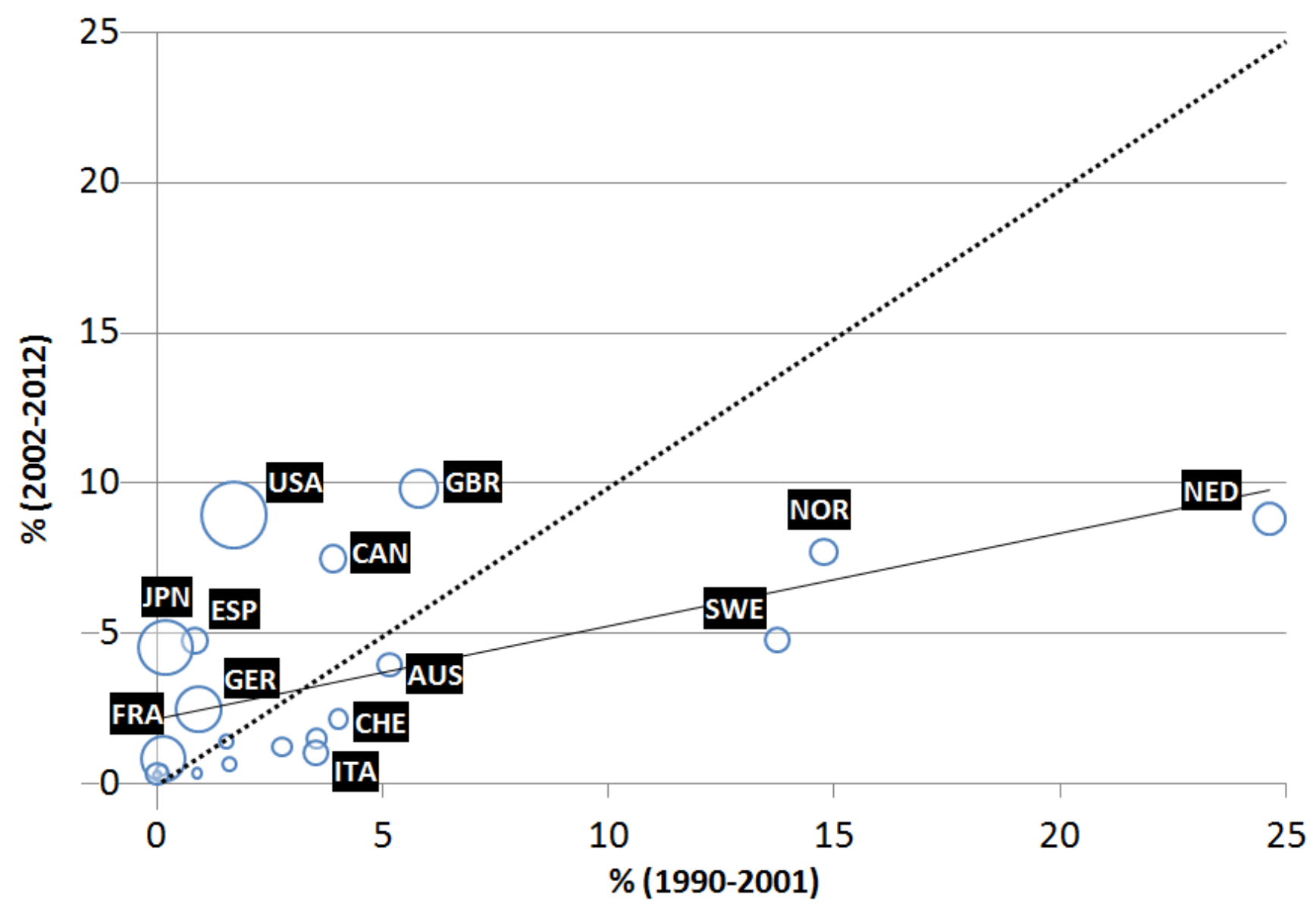

Notes: For each donor, the graph shows the relative importance of the donor country in providing earmarked funding over the respective period (share of a donor's earmarked funding in a period over total earmarked funding by all donors in the period). The dotted line indicates equal importance of a donor in both time periods (45-degree line). Donors with bubbles to the left of the dotted line have become relatively more important in more recent years (2002-2012) while those to the right of the dotted line have declined in importance. The solid line is the line of best fit. The size of the bubbles is determined by donors' total aid from 2002 to 2012. 
Figure 5: The number of multilateral development organizations receiving earmarked aid

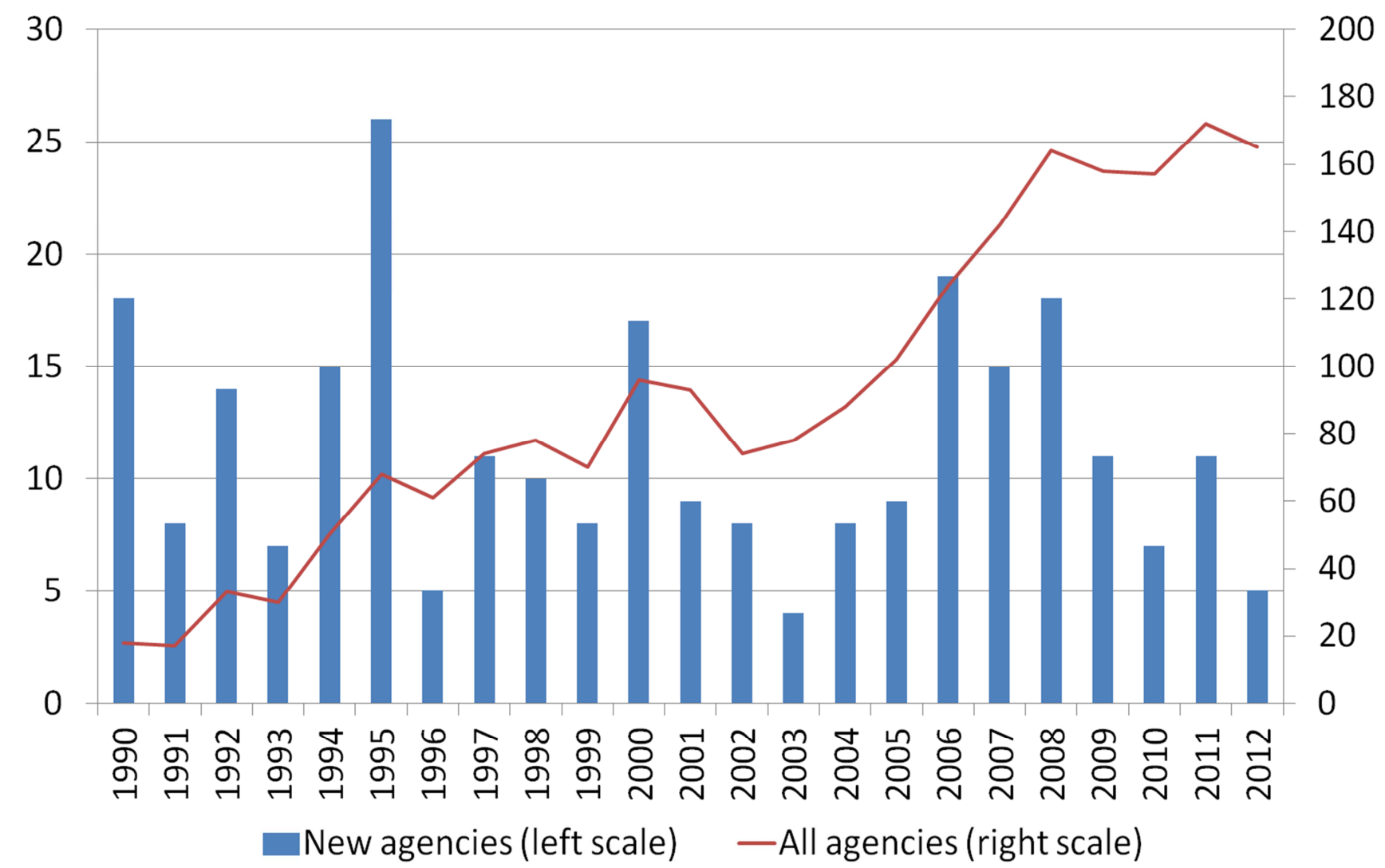

Notes: The columns indicate the number of multilateral organizations (identified by the variable ParentID, see Eichenauer and Reinsberg 2014) first mentioned as recipients of earmarked aid in a given year (right scale). The line shows the total number of multilateral development organizations receiving any earmarked aid in a given year (left scale). 
Figure 6: The intensity of earmarking of multilateral agencies

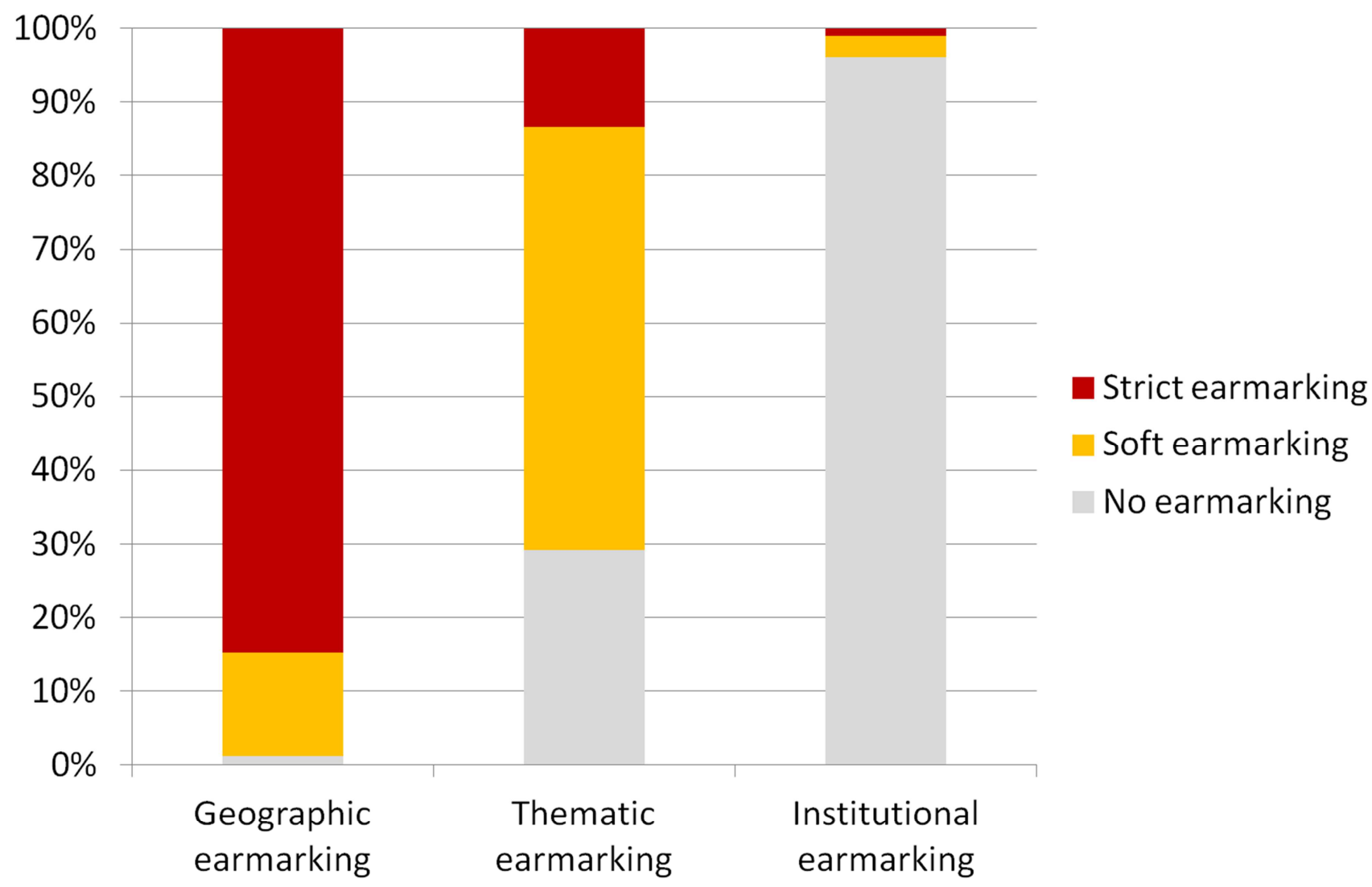

Notes: The graph shows the distribution of earmarking intensity within each earmarking dimension, based on numbers of activities from 1990 to 2012. Earmarking intensity is measured from the perspective of the multilateral agency. All activities are earmarked in at least one dimension, but earmarking dimensions are non-exclusive.

Source: reproduced from Reinsberg et al. (2015a). 
Figure 7: Global and regional activities as share of earmarked aid

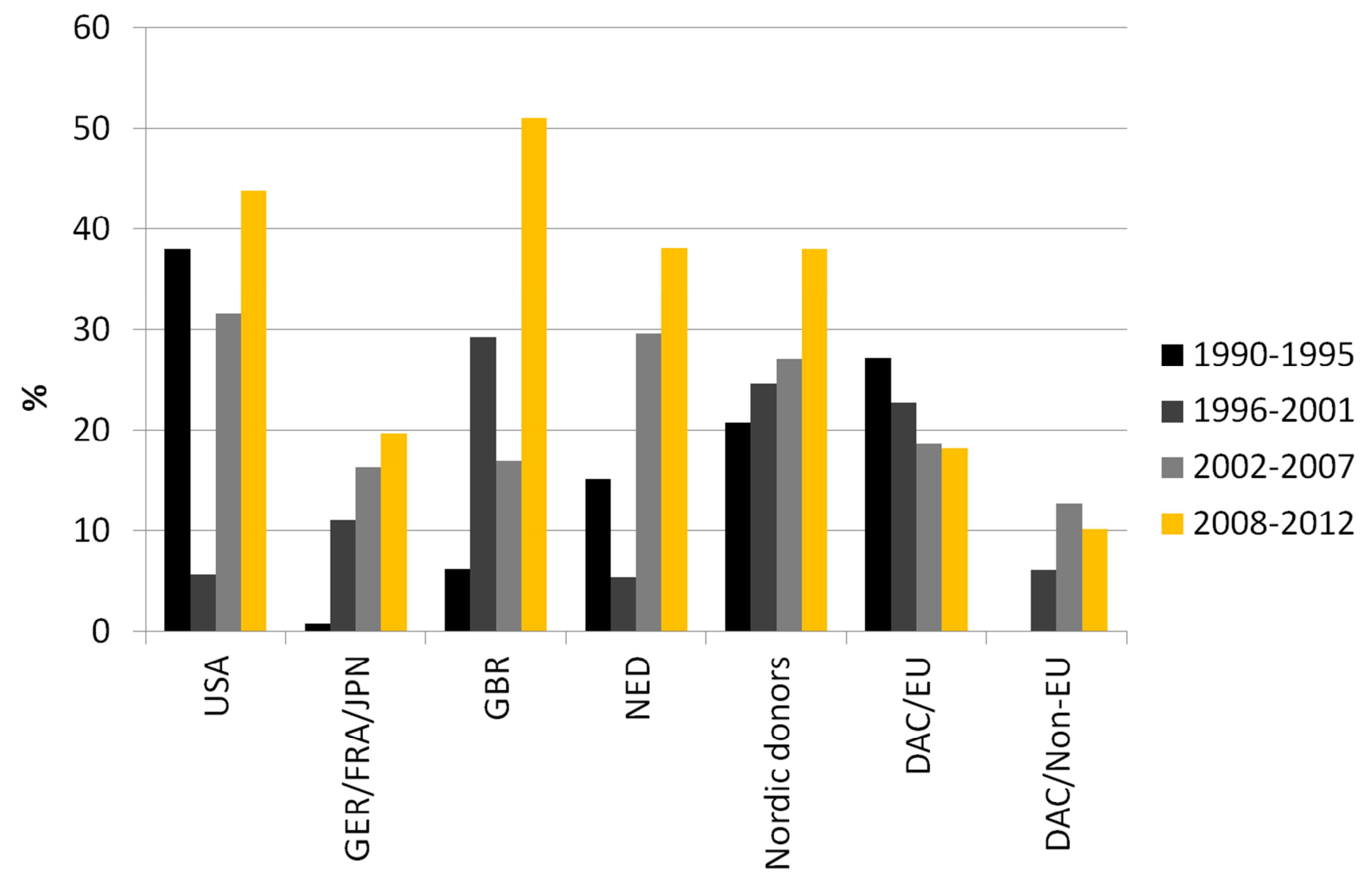

Notes: Global activities are all aid activities that are not earmarked for a specific recipient country. The graph shows the shares of the earmarked aid that is not country-specific as a share of total earmarked aid, averaged over the relevant time period, and, if applicable, over donors. We use the following donor groups: major donors with small shares of earmarked aid (France, Germany, Japan), Nordic countries (Denmark, Sweden, Norway, Finland), European DAC members (Austria, Belgium, Greece, Italy, Ireland, Luxembourg, Portugal, Spain, Switzerland), and non-European DAC members (Australia, Canada, Korea, New Zealand). USA, GBR and NED refer to the United States of America, Great Britain and the Netherlands respectively. 
Figure 8: Earmarked aid to post-conflict countries

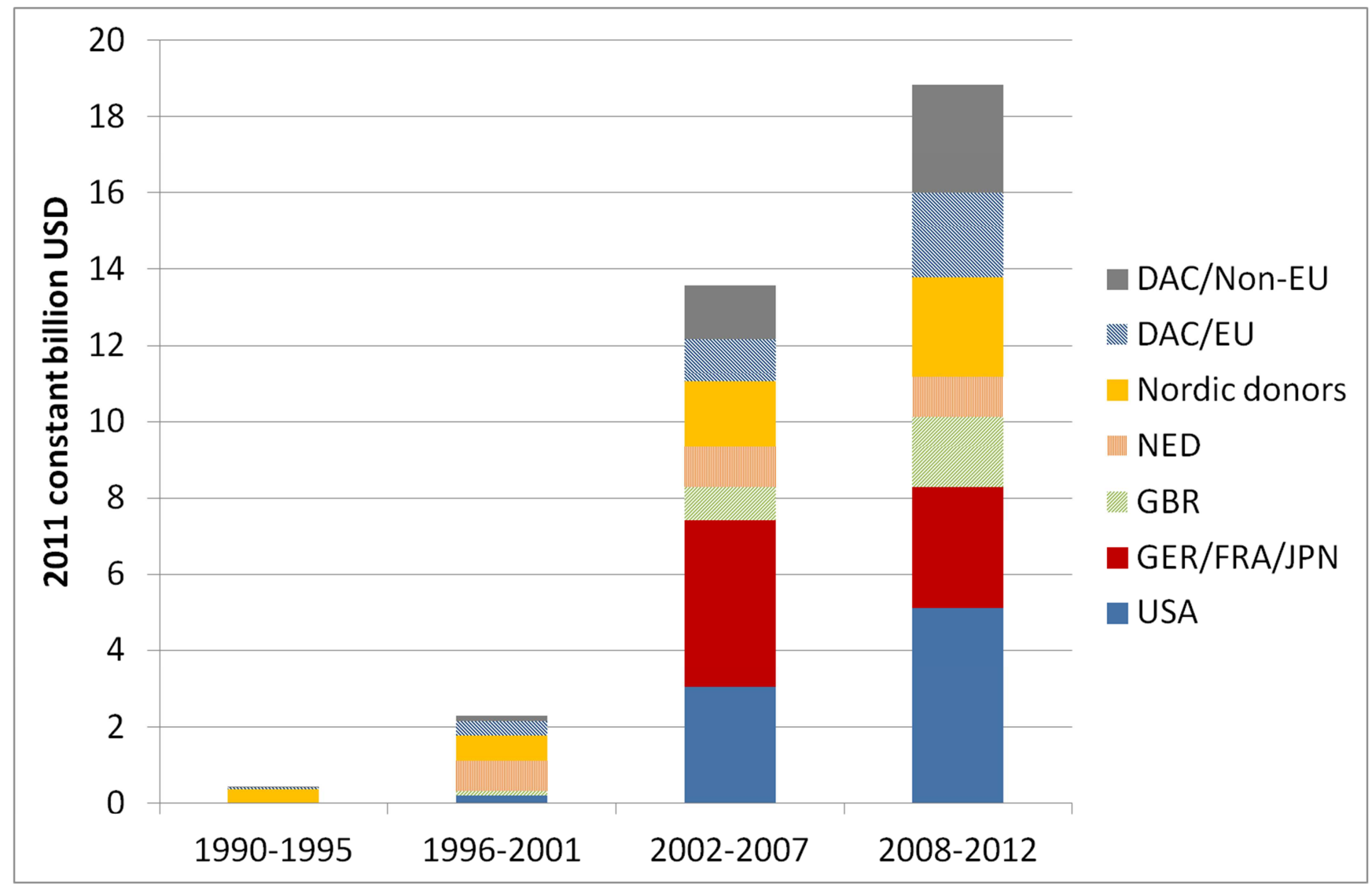

Notes: Earmarked aid to post-conflict countries (i.e., in the first to fifth year after the end of a civil or international war). 
Table 1: Comparing the determinants of bypass aid and earmarked aid

\begin{tabular}{|c|c|c|c|c|c|c|c|c|}
\hline & $\begin{array}{l}\text { Bypass } \\
\text { (1) }\end{array}$ & $\begin{array}{l}\text { Bypass } \\
(2)\end{array}$ & $\begin{array}{l}\text { Earmarked } \\
\text { (3) }\end{array}$ & $\begin{array}{l}\text { Earmarked } \\
\text { (4) }\end{array}$ & $\begin{array}{l}\text { Earmarked } \\
\text { (5) }\end{array}$ & $\begin{array}{l}\text { Earmarked } \\
\text { (6) }\end{array}$ & $\begin{array}{l}\text { Earmarked } \\
\text { (7) }\end{array}$ & $\begin{array}{l}\text { Earmarkeo } \\
\text { (8) }\end{array}$ \\
\hline Recipient governance & $\begin{array}{l}-0.057 \\
(0.195)\end{array}$ & $\begin{array}{l}0.079 \\
(0.194)\end{array}$ & $\begin{array}{l}-0.236 \\
(0.199)\end{array}$ & $\begin{array}{l}-0.213 \\
(0.235)\end{array}$ & $\begin{array}{l}-0.177 \\
(0.149)\end{array}$ & $\begin{array}{l}-0.150 \\
(0.174)\end{array}$ & $\begin{array}{l}-0.184^{*} \\
(0.107)\end{array}$ & $\begin{array}{l}-0.185 \\
(0.124)\end{array}$ \\
\hline $\begin{array}{l}\text { [Recipient governance] x } \\
\text { [Market-oriented donor] }\end{array}$ & $\begin{array}{l}-0.643^{* *} \\
(0.301)\end{array}$ & $\begin{array}{l}-0.811^{* * *} \\
(0.286)\end{array}$ & $\begin{array}{l}-0.855^{*} \\
(0.425)\end{array}$ & $\begin{array}{l}-0.905^{*} \\
(0.454)\end{array}$ & $\begin{array}{l}-0.838 * * \\
(0.350)\end{array}$ & $\begin{array}{l}-0.866 * * \\
(0.377)\end{array}$ & $\begin{array}{l}-0.430^{*} \\
(0.223)\end{array}$ & $\begin{array}{l}-0.398 \\
(0.233)\end{array}$ \\
\hline Recipient disasters (In) & $\begin{array}{l}0.446 * * \\
(0.163)\end{array}$ & $\begin{array}{l}0.520 * * * \\
(0.167)\end{array}$ & $\begin{array}{l}0.198 \\
(0.223)\end{array}$ & $\begin{array}{l}0.281 \\
(0.222)\end{array}$ & $\begin{array}{l}0.115 \\
(0.184)\end{array}$ & $\begin{array}{l}0.211 \\
(0.196)\end{array}$ & $\begin{array}{l}0.114 \\
(0.129)\end{array}$ & $\begin{array}{l}0.179 \\
(0.138)\end{array}$ \\
\hline Post-conflict country & $\begin{array}{l}-0.154 \\
(0.198)\end{array}$ & $\begin{array}{l}-0.091 \\
(0.199)\end{array}$ & $\begin{array}{l}0.063 \\
(0.336)\end{array}$ & $\begin{array}{l}0.097 \\
(0.356)\end{array}$ & $\begin{array}{l}0.294 \\
(0.246)\end{array}$ & $\begin{array}{l}0.381 \\
(0.274)\end{array}$ & $\begin{array}{l}0.314^{*} \\
(0.157)\end{array}$ & $\begin{array}{l}0.363^{* *} \\
(0.166)\end{array}$ \\
\hline Bilateral presence & $\begin{array}{l}0.135 \\
(0.793)\end{array}$ & $\begin{array}{l}0.490 \\
(0.645)\end{array}$ & $\begin{array}{l}3.055^{* * *} \\
(0.367)\end{array}$ & $\begin{array}{l}3.144 * * * \\
(0.408)\end{array}$ & $\begin{array}{l}2.825^{* * *} \\
(0.351)\end{array}$ & $\begin{array}{l}2.870 * * * \\
(0.377)\end{array}$ & $\begin{array}{l}2.144 * * * \\
(0.336)\end{array}$ & $\begin{array}{l}2.228 * * * \\
(0.309)\end{array}$ \\
\hline Donor fixed effects & Yes & Yes & Yes & Yes & Yes & Yes & Yes & Yes \\
\hline Donor controls & No & Yes & No & Yes & No & Yes & No & Yes \\
\hline Recipient fixed effects & No & No & No & No & No & No & No & No \\
\hline Recipient controls & Yes & Yes & Yes & Yes & Yes & Yes & Yes & Yes \\
\hline Period & 2005-11 & 2005-11 & 2005-11 & $2005-11$ & $2002-12$ & $2002-12$ & $1990-12$ & $1990-12$ \\
\hline Observations & 11247 & 10377 & 11247 & 10377 & 16534 & 14196 & 24819 & 21742 \\
\hline Number of donors & 23 & 23 & 23 & 23 & 23 & 23 & 23 & 23 \\
\hline Adjusted R2 & 0.33 & 0.34 & 0.22 & 0.22 & 0.22 & 0.22 & 0.21 & 0.21 \\
\hline
\end{tabular}

Notes: Dependent variable is the natural logarithm of bypass aid (Bypass) or earmarked aid (Earmarked) at the donor-recipient dyad level. All estimations include year-fixed effects. If included, donor controls are GDP per capita (In), political globalization, trade openness, social expenditure, and public debt. Recipient controls include GDP per capita (In), population (In), UNGA vote alignment, former colony, and trade openness. Robust standard errors in brackets, clustered at the donor country level. ${ }^{*} p<0.10,{ }^{* *} p<0.05,{ }^{* * *} p<0.01$ 
Table 2: The determinants of earmarked aid for specific donor countries

\begin{tabular}{|c|c|c|c|c|c|c|c|c|c|}
\hline & $\begin{array}{l}\text { USA } \\
\text { (1) }\end{array}$ & $\begin{array}{l}\text { JPN } \\
\text { (2) }\end{array}$ & $\begin{array}{l}\text { GBR } \\
\text { (3) }\end{array}$ & $\begin{array}{l}\text { DEU } \\
\text { (4) }\end{array}$ & $\begin{array}{l}\text { FRA } \\
\text { (5) }\end{array}$ & $\begin{array}{l}\text { NED } \\
(6)\end{array}$ & $\begin{array}{l}\text { SWE } \\
\text { (7) }\end{array}$ & $\begin{array}{l}\text { NOR } \\
\text { (8) }\end{array}$ & $\begin{array}{l}\text { CAN } \\
\text { (9) }\end{array}$ \\
\hline Recipient governance & $\begin{array}{l}-1.729 * * * \\
(0.336)\end{array}$ & $\begin{array}{l}-0.445 \\
(0.351)\end{array}$ & $\begin{array}{l}0.666 \\
(0.416)\end{array}$ & $\begin{array}{l}-0.308 \\
(1.531)\end{array}$ & $\begin{array}{l}-0.292 \\
(0.365)\end{array}$ & $\begin{array}{l}-0.047 \\
(0.561)\end{array}$ & $\begin{array}{l}-1.293^{* *} \\
(0.530)\end{array}$ & $\begin{array}{l}-0.650 \\
(0.426)\end{array}$ & $\begin{array}{l}-1.369 * * * \\
(0.420)\end{array}$ \\
\hline Recipient disasters (In) & $\begin{array}{l}0.196 \\
(0.384)\end{array}$ & $\begin{array}{l}0.400 \\
(0.397)\end{array}$ & $\begin{array}{l}0.727 \\
(0.508)\end{array}$ & $\begin{array}{l}-3.355^{* *} \\
(1.493)\end{array}$ & $\begin{array}{l}-0.468 \\
(0.455)\end{array}$ & $\begin{array}{l}0.823 \\
(0.641)\end{array}$ & $\begin{array}{l}0.408 \\
(0.585)\end{array}$ & $\begin{array}{l}0.353 \\
(0.507)\end{array}$ & $\begin{array}{l}0.684 \\
(0.500)\end{array}$ \\
\hline Post-conflict country & $\begin{array}{l}0.476 \\
(0.444)\end{array}$ & $\begin{array}{l}1.744^{* * *} \\
(0.489)\end{array}$ & $\begin{array}{l}2.032 * * * \\
(0.580)\end{array}$ & $\begin{array}{l}0.222 \\
(2.171)\end{array}$ & $\begin{array}{l}-0.260 \\
(0.511)\end{array}$ & $\begin{array}{l}1.264^{*} \\
(0.677)\end{array}$ & $\begin{array}{l}0.334 \\
(0.642)\end{array}$ & $\begin{array}{l}2.597^{* * *} \\
(0.528)\end{array}$ & $\begin{array}{l}0.742 \\
(0.565)\end{array}$ \\
\hline Bilateral presence & $\begin{array}{l}5.297^{* * *} \\
(1.237)\end{array}$ & $\begin{array}{l}-2.204^{*} \\
(1.266)\end{array}$ & $\begin{array}{l}3.116^{* * *} \\
(0.522)\end{array}$ & $\begin{array}{l}1.500 \\
(2.502)\end{array}$ & --- & $\begin{array}{l}3.410^{* * *} \\
(0.859)\end{array}$ & $\begin{array}{l}4.620^{* * *} \\
(0.574)\end{array}$ & $\begin{array}{l}4.998 * * * \\
(0.642)\end{array}$ & $\begin{array}{l}2.565^{* *} \\
(1.161)\end{array}$ \\
\hline Recipient controls & Yes & Yes & Yes & Yes & Yes & Yes & Yes & Yes & Yes \\
\hline Donor controls & Yes & Yes & Yes & Yes & Yes & Yes & Yes & Yes & Yes \\
\hline Period & $2002-12$ & $2002-12$ & $2002-12$ & $2002-12$ & $2002-12$ & $2002-12$ & $2002-12$ & $2002-12$ & $2002-12$ \\
\hline Observations & 867 & 874 & 725 & 85 & 340 & 650 & 665 & 738 & 816 \\
\hline Adjusted R2 & 0.47 & 0.32 & 0.35 & 0.05 & 0.11 & 0.16 & 0.15 & 0.29 & 0.34 \\
\hline
\end{tabular}

Notes: Dependent variable is the natural logarithm of earmarked aid at the recipient level. All estimations include year-fixed effects and the recipient and donor controls as listed in the notes to Table 1. The country abbreviations refer, from left to right, to the United States, Japan, the United Kingdom, Germany, France, the Netherlands, Sweden, Norway, and Canada. Robust standard errors in brackets, clustered at the donor country level. $* p<0.10, * * p<0.05, * * * p<0.01$ 